\title{
Harnessing Politics: The Dynamics of Offset Requirements in the Tax Legislative Process
}

\author{
Elizabeth Garrett $\dagger$
}

TABLE OF CONTENTS

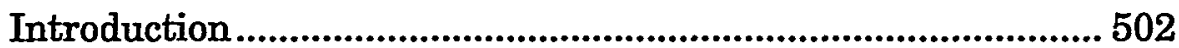

I. Offset Requirements for Tax Legislation: PAYGO

and Other Provisions................................................................ 507

II. Offset Requirements Reduce the Level of New Federal

Spending...........................................................................514

A. PAYGO Increases the Cost of Enacting New Tax

Expenditures

B. Gimmicks and Downstreaming: Avoiding the

High Costs of PAYGO

1. Timing Gimmicks that Manipulate the Limited Budget Window.

2. Downstreaming Decisions to the Executive Branch

C. Offset Requirements Impose Post-Enactment

Costs on Recipients of Tax Benefits.

D. Legislators' Motivations for Adopting Offset

Requirements 543

$\dagger$ Assistant Professor of Law, University of Chicago. I appreciate the helpful comments of Anne Alstott, Douglas Baird, Mike Bresson, Emily Buss, Stephen Choi, Ellen Cosgrove, Dick Craswell, Chris Drahozal, Richard Epstein, Dan Farber, Phil Frickey, Barry Friedman, Nick Giordano, Jack Goldsmith, Michael Graetz, Dan Kahan, Karin Kizer, John Manning, Kevin Marshall, Fred McChesney, Tracey Meares, Eric Posner, Mark Ramseyer, Glen Robinson, Dan Shaviro, Nancy Staudt, Mark Weinberger, David Weisbach, and participants at the 1997 Harvard Seminar on Current Research in Taxation, the University of Buffalo Law School's Workshop on Taxation in a Democracy, and Georgetown University Law Center's Tax Policy Workshop; the insights of participants in my Spring 1997 seminar on Federal Budget Policy; the invaluable aid of Connie Fleischer; and the excellent research assistance of Donald Bly. I am also grateful for the financial support of the Russell Baker Scholars Fund at the University of Chicago Law School. 
III. Offset Requirements Result in Congressional Scrutiny of Existing Tax Expenditures ............................................555

A. Offset Requirements Provide Congress with More Information About Tax Expenditures .......................... 556

B. Offset Requirements Operate as a Surrogate for Institutionalized Tax Expenditure Review ................... 561

Conclusion 569

\section{INTRODUCTION}

Over fifty years ago, V.O. Key decried the lack of a comprehensive budgetary theory for government: "[T] energies in the establishment of the mechanical foundation for budgeting has diverted attention from the basic budgeting problem ... namely: On what basis shall it be decided to allocate $x$ dollars to activity A instead of activity B?' Key's quest was utopian. The question of how to allocate scarce governmental resources is political; neutral principles will not provide answers. Furthermore, the structure of decisionmaking, or as Professor Key dismissively labeled it, the "mechanical foundation for budgeting," matters greatly. By shaping the choices that are presented to lawmakers, this structure sets the bounds of the allocational decisions that so concerned Key. Better "mechanical" rules lead to more appropriate tradeoffs among the competing claims on limited resources. Process is vital, regardless of whether lawmakers and citizens are seeking to change the level of spending or are struggling to divide a pie of unchanging size.

Congressional budget procedures affecting tax legislation have assumed greater importance during the past two decades as several economic and political developments have constrained available revenue. Before the mid-1980s, lawmakers had little trouble retaining existing tax expenditures ${ }^{2}$ and funding new

2 V.O. Key, Jr., The Lack of a Budgetary Theory, 34 Am Pol Sci Rev 1137, 1138 (1940). See also id at 1143-44 ("TT]he question is a problem in political philosophy. . . . The discussion also suggests the desirability of careful and comprehensive analyses of the budgetary process."); Aaron B. Wildavsky, The New Politics of the Budgetary Process xvi (Scott, Foresman 1988) ("Now that budgeting has acquired some of the interested audience it deserves, the subject unfortunately has become too difficult to describe. I hope again to show that the effort to understand is worthwhile. Budget, budget, budget, as congressmen complain, is all we can do unless and until we Americans once again agree on what kind of society, and which sort of government, we want.").

2 The Congressional Budget and Impoundment Control Act of 1974 defines tax expenditures as "revenue losses attributable to provisions of the Federal tax laws which allow a special exclusion, exemption, or deduction from gross income or which provide a special credit, a preferential rate of tax, or a deferral of tax liability." Pub L No 93-344 $\S 3(\mathrm{a})(3), 88$ Stat 297, codified at 2 USC § 622(3) (1994). 
ones, in part because bracket creep ${ }^{3}$ fueled by high inflation automatically increased income tax rates and provided new revenue. In such an environment, Congress usually could avoid making explicit tradeoffs among tax expenditures or identifying the groups who were paying higher taxes to fund the subsidies of others. Beginning in 1985, Congress indexed tax brackets for inflation, thus eliminating this fiscal illusion. ${ }^{5}$ In addition, the greater political salience of the federal deficit caused Congress to adopt new budget rules. These rules both restricted Congress's ability to place the costs of new federal programs on future generations and increased the pressure to use new tax revenues for deficit reduction rather than for new tax subsidies. As lawmakers hunted for ways to maintain current benefits or establish new programs, interest groups that benefited from tax expenditures found themselves increasingly in danger of losing federal funds they had expected to receive in perpetuity.

Budget rules, along with indexing, both demand and highlight tradeoffs among federal beneficiaries. Intricate offset provisions dominate federal budgeting, shaping decisions regarding annual appropriations, entitlement legislation, and the tax code. They require advocates of new spending to find revenue offsets, and they limit the kinds of programs that can be eliminated or scaled back to pay for particular kinds of new spending. Increasingly, the losers in the competition for scarce resources know exactly who they are, and those with organization and clout fight vigorously to retain their governmental subsidies. This heightened awareness of the zero-sum nature of federal allocative decisions is perhaps the most important change in modern federal budgeting.

This Article considers the budget rules that shape these tradeoffs in the tax arena, most notably, the "pay-as-you-go" provision ("PAYGO") enacted in the Budget Enforcement Act of $1990 .^{6}$ PAYGO requires advocates for new tax expenditures to pay for them in one of three ways: raising taxes, reducing current

3 Until tax brackets were indexed for inflation, tax rate increases occurred automatically as a taxpayer's higher nominal income (largely a result of inflation) would move her into a higher tax bracket and increase her effective tax rate, even though her real income remained unchanged. This phenomenon is known as bracket creep.

4 C. Eugene Steuerle, The Tax Decade: How Taxes Came to Dominate the Public Agenda 73 (Urban 1992) (calling this the "easy financing period"). See also Joseph A. Pechman, Federal Tax Policy 114-16 (Brookings 5th ed 1987) (explaining bracket creep).

- Economic Recovery Tax Act of 1981, Pub L No 97-34, 95 Stat 172, 188, codified at 26 USC $\S 1$ (1994). The indexation became effective after 1984. 95 Stat at 190.

- Title XIII, Pub L No 101-508, 104 Stat 1388-573, codified as amended at 2 USC $\S 902$ (1994). 
tax subsidies, or reducing spending for existing entitlement programs. The dynamics of the committee structure limit groups that employ the third strategy to offsets in entitlement programs within the jurisdiction of the tax writing committees, such as Medicare, Medicaid, Social Security, or welfare. Importantly, budget rules virtually eliminate the possibility of using programs that receive annual appropriations as offsets for new tax expenditures or entitlement programs.

I argue that these rules are a mechanism to harness the interest group activity that is already ubiquitous in the tax legislative arena in order to reach substantive policy goals more easily. ${ }^{7}$ In addition, such conflict provides lawmakers with opportunities to review and revise tax subsidies. The structure of this process encourages legislators to provide reasons for their decisions, thus increasing their accountability to the electorate. Previous scholarship has not provided this perspective. The possible benefits of congressional rules that use interest group conflict have been ignored or undervalued by the few scholars who have studied them in the context of tax legislation and by budget scholars generally. Aaron Wildavsky, the most influential budget scholar of the past several decades, ${ }^{8}$ seemed to favor relatively consensual decisionmaking. He was the primary exponent of "incrementalism" and

7 For purposes of this Article, I will use the term "interest group" to refer to "any group that, on the basis of one or more shared attitudes, makes certain claims upon other groups in the society for the establishment, maintenance, or enhancement of forms of behavior that are implied by the shared attitudes." David B. Truman, The Governmental Process: Political Interests and Public Opinion 33 (Knopf 1965). See also Peter H. Schuck, Against (And For) Madison: An Essay in Praise of Factions, 15 Yale L \& Policy Rev 553, 557-58 (1997) (defining "special interest" as "any group that pursues contested political or policy goals, and that is widely regarded by the public as being one contending interest among others"). But see Elizabeth Garrett, Term Limitations and the Myth of the CitizenLegislator, 81 Cornell L Rev 623, 683-84 n 201 (1996) (explaining the difficulty of choosing a "neutral" definition of interest group).

8 Among his many publications are three editions of The Politics of the Budgetary Process and three editions of The New Politics of the Budgetary Process (the last published posthumously and coauthored by Naomi Caiden). See, for example, Aaron B. Wildavsky and Naomi Caiden, The New Politics of the Budgetary Process (Longman 3d ed 1997).

- In the budget context, "incrementalism is a process in which budgetary bases (i.e., previous expenditures) are accepted, and decision making is focused on the change from the base. ... [I]n an incremental process, 'budgeting is a stable process in which individual allocative decisions are sufficiently independent of one another so that tradeoffs are only implicit, and conflict is thereby minimized." William D. Berry, The Confusing Case of Budgetary Incrementalism: Too Many Meanings for a Single Concept, 52 J Pol 167, 171-72 (1990), quoting John R. Gist, "Stability" and "Competition" in Budgetary Theory, 76 Am Pol Sci Rev 859, 859 (1982). See Aaron B. Wildavsky, The Politics of the Budgetary Process 136 (Little, Brown 2d ed 1974) ("Conflict is reduced by an incremental approach because the area open to dispute is reduced."); Wildavsky, New Politics at 439 (cited in note 1) ("Only a political system so polarized that it cannot make [allocation] choices through the usual legislative, executive, and party mechanisms ... would arrive at a general formula 
defended it in part as a technique that reduced conflict among budget players. ${ }^{10}$

Although Professor Wildavsky was one of the most astute observers of the modern budget process, his normative approach is flawed for current conditions. A theory that ignores or downplays interest group conflict is not only ill-suited to a world of constrained revenues, it also lacks the information-forcing and information-structuring advantages I describe. Rather than quixotically fighting the power of interest groups, as Professor Wildavsky would do, we should try to harness it. The budget rules can thus be seen as an application of a basic Madisonian insight. Madison believed that the opportunities for factional activity are greatest in "[t]he apportionment of taxes." ${ }^{\text {"11 }}$ The trick, he argued, is to further the public good by finding rules that will force these "opposite and rival interests," through their selfinterested battles, to "supply[ ] . . . the defect of better motives." PAYGO and related rules are part of such a political strategy.

In Part I of this Article, I describe the PAYGO rules and other congressional offset requirements that affect tax bills. A sustained analysis of the rules and procedures that shape tax lawmaking is not a typical approach for legal scholars. Traditional scholarship has been focused on the outcomes produced through the tax legislative process; commentators have worked to rationalize tax laws with tax policy norms such as equity, efficiency, and simplicity. My objective is to describe the process that determines legislative outcomes, which should not only help to explain them, but also may allow us to anticipate the political

(e.g. Gramm-Rudman-Hollings) for maximizing discontent rather than trying to agree, case by case, on reasonable choices."). But see Wildavsky and Caiden, New Politics at 26466 (cited in note 8) (acknowledging that some amount of conflict is inevitable in budgeting). See also Roy T. Meyers, Strategic Budgeting 9 (Michigan 1994) (describing challenges to "incrementalism's consensual bargaining component" and arguing that "competition is rife in budgeting"); id at 15 ("Another lesson from the criticisms of incrementalism is that we must recognize that budgeting is an especially competitive process."); Howard E. Shuman, Politics and the Budget: The Struggle Between the President and Congress xiv (Prentice Hall 3d ed 1992) (stating that the budget "is not a process but a tale of conflict and struggle[,] . . . a barroom brawl"); Eric A. Hanushek, Formula Budgeting: The Economics and Analytics of Fiscal Policy under Rules, $6 \mathrm{~J}$ Pol Analysis \& Mgmt 3, 16 (1986) (suggesting that a weakness of "distributional data" in the budget process is that it leads "to continuing conflict in budgetary debates, conflict that is intensified in times of general cutbacks").

${ }^{10}$ In his later writings, Wildavsky referred to incrementalism as "classical budgeting," see, for example, Wildavsky, New Politics at 70 (cited in note 1), indicating the increased influence of different approaches and the changing environment of budgeting.

${ }^{11}$ Federalist 10 (Madison), in Clinton Rossiter, ed, The Federalist Papers 77, 80 (Mentor 1961).

${ }^{12}$ Federalist 51 (Madison), in Rossiter, ed, The Federalist Papers 320, 322. 
forces that will prevail over time. Congress adopted offset requirements in order to control federal spending, more particularly, to reduce the ability of interest groups and others to receive new or increased federal benefits. Unlike some budget procedures that were designed to reduce the federal deficit, PAYGO merely restrains future growth; it does not directly affect spending for previously enacted tax subsidies and entitlement programs. Although others have concluded that the rules have been successful in this deficit control goal, ${ }^{13}$ no one has provided a comprehensive description of how such procedures have raised the costs of enacting new federal programs. In Part II of this Article, I provide just such an analysis. In addition, I discuss the puzzle of why legislators, who generally prefer to enact new federal programs, might have adopted rules that make it more difficult to do so.

Virtually the only praise for PAYGO and offset requirements in the tax arena has been for their ability to restrain new spending; otherwise, they tend to be criticized on tax policy grounds. Some commentators have argued that budget rules unnecessarily increase the complexity of the tax law, and that they conflict with tax policy goals such as equity and efficiency. ${ }^{14}$ Others have worried that the rules entrench status quo programs and tax subsidies, while placing substantial obstacles in the path of new proposals, some of which may be better uses of federal money. ${ }^{15}$ In

${ }^{13}$ See, for example, James A. Thurber, Twenty Years of Congressional Budget Reform, 25 The Public Manager: The New Bureaucrat 6, 7 (1996) ("The primary impact of PAYGO has been to discourage spending. The difficulty of either raising taxes or cutting popular existing mandatory programs has effectively closed out new mandatory programs."); Allen Schick, The Federal Budget: Politics, Policy, Process 41 (Brookings 1995) (“[PAYGO] has had a marked effect on new legislation .... Congress has achieved substantial deficit reduction by increasing revenue and cutting direct spending under existing law while also offsetting any deficit increases resulting from new legislation."); Philip G. Joyce and Robert D. Reischauer, Deficit Budgeting: The Federal Budget Process and Budget Reform, 29 Harv J Leg 429, 438 (1992) ("The PAYGO process seems to have discouraged major efforts to increase entitlement spending or cut taxes or both.").

" See, for example, Robert D. Reischauer, Taxes and Spending under GrammRudman-Hollings, 43 Natl Tax J 223, 230 (1990) ("[T]he tax debate [in the context of budget reconciliation packages and under Gramm-Rudman-Hollings rules] has focused more on the revenue repercussions of pending legislation and less on its policy merits."); Bernard M. Shapiro, Complexity in the Tax Legislative Process: Problems and Proposals; Role of Congressional Staff and Taxpayer Representatives, in Tax Management, Proceedings of the Invitational Conference on Reduction of Income Tax Complexity I-J-1, I-J-33 (GPO 1990) ("The pressures of deficit reduction, combined with the short time periods during which reconciliation bills have been produced, have strained the tax legislative process significantly. This has resulted in revenue-driven bills that have increased the complexity of the tax system enormously."); Gene Steuerle, Fair Budget Policy, Bad Tax Policy, Tax Notes 455 (July 24, 1989) ("As a matter of tax policy ... the [deficit reduction] rules have not worked well, and the tax code is again being made more complex and more unfair.").

${ }^{15}$ See, for example, Joyce and Reischauer, 29 Harv J Leg at 442 ("The discretionary 
Part III, I suggest a previously unidentified benefit of offset requirements: they provide Congress with an opportunity to assess, modify, or repeal existing tax expenditures. PAYGO may not only increase the amount of information about tax expenditures that private sources produce, but the structure for disclosure that it erects may allow lawmakers to understand and use relevant information more appropriately. This consequence somewhat mitigates PAYGO's bias in favor of the status quo. My conclusions in this Part rest on theory and anecdotal evidence and thus are preliminary. Nevertheless, this study lays the foundation for further empirical analysis.

\section{OFFSET REQUIREMENTS FOR TAX LEGISLATION: PAYGO AND OTHER PROVISIONS}

The 1990 Budget Enforcement Act is the most significant recent amendment to the fiscal constitution. ${ }^{16}$ Included within it is the PAYGO provision relating to tax and direct spending (largely, entitlement) legislation. ${ }^{17}$ The Act is the latest addition to an evolving congressional institution that began largely as a response to clashes with the executive branch and was maintained because of public concern with rising federal deficits.

The first major modern budget law, the Congressional Budget and Impoundment Control Act of 1974, ${ }^{18}$ ("Budget Act"19) was a vehicle to allow Congress more control over its appropriations process and to coordinate the actions of dozens of committees that participated in federal budgeting. ${ }^{20}$ Through these pro-

spending caps ... may do more to freeze out new initiatives ... in favor of old ones ... than to kill low priority programs."); Wildavsky and Caiden, New Politics at 150 (cited in note 8) (arguing that discretionary spending caps favor established programs). In contrast to these critics, Professor Schuck has suggested that PAYGO and other offset requirements that establish a zero-sum game may diminish the distortions of the "logrolling game." See Schuck, 15 Yale L \& Policy Rev at 593-94 (cited in note 7). This statement, though brief, is consistent with some of my conclusions; the detail I provide may justify Schuck's decision to label offset requirements as a political "reform."

${ }^{16}$ This term was first used in legal scholarship by Kenneth Dam in The American Fiscal Constitution, 44 U Chi L Rev 271 (1977).

${ }^{17}$ Entitlement spending, which is also sometimes called mandatory spending, is actually a subset of direct spending. Direct spending is any spending pursuant to a binding legal obligation to pay, including, for example, interest on the national debt. Entitlement spending is by far the largest component of direct spending and is usually the kind of mandatory spending relevant to PAYGO.

${ }^{18}$ Pub L No 93-344, 88 Stat 297, codified at 2 USC $\$ \S 601-88$ (1994).

20 Throughout this Article, the term "Budget Act" is used to refer to the Congressional Budget and Impoundment Control Act of 1974, as amended. The 1974 Act, as amended, provides the basic framework for contemporary budget law.

${ }^{20}$ See generally Allen Schick, Congress and Money: Budgeting, Spending, and Taxing (Urban 1980) (detailing the events that led to the passage of the Budget Act, its legislative 
visions and restrictions on the President's power to impound federal funds, the legislative branch reclaimed some of its power of the purse. These congressional rules can be divided into "process rules," which merely govern how a decision is reached, and "outcome-oriented rules," which are explicitly designed to facilitate particular decisions. ${ }^{21}$ The Budget Act's framework is described most accurately as one of the former; its process was "neutral on its face" and could be "deployed in favor of higher or lower spending, bigger or smaller deficits."

The next amendment to the fiscal constitution was unabashedly outcome-oriented; the Gramm-Rudman-Hollings Act ("GRH"), enacted in 1985 , aimed to eliminate the deficit by $1991 .^{23}$ In some cases, GRH required proponents of new discretionary programs to offset new spending by eliminating or reducing existing programs. ${ }^{24}$ The requirement for such tradeoffs, however, was limited to the discretionary spending arena, which was controlled by the appropriations committees. Although annual congressional budget resolutions might require the tax writing committees to increase revenues or cut entitlement spending, GRH was primar-

history, and its major provisions).

${ }^{21}$ Hanushek, $6 \mathrm{~J}$ Pol Analysis \& Mgmt at 6 (cited in note 9).

2 Schick, Congress and Money at 73 (cited in note 20). See also Philip G. Joyce, Congressional Budget Reform: The Unanticipated Implications for Federal Policy Making, 56 Pub Admin Rev 317, 318 (1996) ("The act was outcome neutral, truly a process reform."). As with any attempt to distinguish procedure from substance, these statements are somewhat misleading: no process is truly neutral. See Ronald F. King, Money, Time and Politics: Investment Tax Subsidies \& American Democracy 1 (Yale 1993) ("Politics is a structured activity. Its practices are governed by rules, norms, beliefs, and agreements that define the players, the goals they can pursue, and the means appropriate for pursuing them. ... The structures of political life are not neutral in their effects. They all help determine the types of issues that appear on the political agenda, the kinds of actors who struggle over those issues, the form of that struggle, and the probable policy result."). By allowing more coordination in the congressional budget process, the Budget Act strengthened the power of the legislative branch relative to the executive branch, created new budget players such as the budget committees and the Congressional Budget Office ("CBO"), and weakened the appropriations committees. But relative to the subsequent budget acts-which explicitly sought to reduce federal spending or balance the budget, or both-the Budget Act is a process, rather than outcome-oriented, rule.

${ }^{23}$ Balanced Budget and Emergency Deficit Control Act of 1985, Pub L No 99-177, 99 Stat 1037, codified as amended at 2 USC $\$ \$ 900-08,922$ (1994). Congress amended GRH in 1987, postponing the balanced budget until 1993. See Balanced Budget and Emergency Deficit Control Act of 1987, Pub L No 100-119, 101 Stat 754, codified at 2 USC $\S 901$ (1994). For discussions of the legislative history and provisions of GRH, see generally Rudolph G. Penner and Alan J. Abramson, Broken Purse Strings: Congressional Budgeting, 1974 to 1988 (Urban 1988); Allen Schick, The Capacity to Budget (Urban 1990).

${ }^{24}$ See Kate Stith, Rewriting the Fiscal Constitution: The Case of Gramm-RudmanHollings, 76 Cal L Rev 593, 626 (1988) (explaining this “deficit neutrality" rule). 
ily concerned with controlling the annual appropriations process and reducing discretionary spending. ${ }^{25}$

The informal norm of revenue neutrality in tax legislation, the precursor of PAYGO, developed during the early years of GRH when the tax writing committees adopted it during their consideration of the Tax Reform Act of $1986 .{ }^{26}$ The requirement of revenue neutrality meant that tax legislation could neither lose nor raise revenue; any money lost through tax rate reductions or new tax subsidies had to be offset by provisions raising revenue. The Senate Finance and House Ways and Means Committees adopted this norm to keep the Tax Reform Act free from budget rules and outside the jurisdiction of the budget committees. ${ }^{27}$ In addition, the decision of the tax writing committees to apply the norm to any proposed amendment to the chairman's proposal (called "the mark") was an effective way to discourage amendments and prevent tax reform from unraveling. ${ }^{28}$ Undoubtedly, lawmakers developed and applied the norm because the notion of offsets was particularly salient after the adoption of GRH and because it seemed an effective way to discourage new spending programs in the form of tax expenditures.

While congressional rules like those of GRH shape informal norms, the process also works in reverse; norms can shape new congressional rules. ${ }^{29}$ Such was the case with PAYGO, which both

${ }^{25}$ Id at 655-57 (noting that GRH exempted federal entitlements and tax expenditures); Stanley S. Surrey and Paul R. McDaniel, Tax Expenditures 33 (Harvard 1985) (describing tax expenditures as "largely uncontrolled" under budget procedures of the time).

${ }^{26}$ Pub L No 99-514, 100 Stat 2085, codified at numerous sections of 26 USC (1994).

${ }^{27}$ Schick, Capacity to Budget at 134 (cited in note 23). In addition, "revenue . . . neutrality constraints were largely pursued to prevent policymakers from diverting their attention from the tough choices necessary to reduce inequities and promote the efficient allocation of resources." Steuerle, The Tax Decade at 107 (cited in note 4). See also Jeffrey H. Birnbaum and Alan S. Murray, Showdown at Gucci Gulch: Lawmakers, Lobbyists, and the Unlikely Triumph of Tax Reform 29 (Random House 1987) (stating that Senator Bradley favored revenue neutrality "to avoid the harsh ideological battles that would undoubtedly follow if he pushed his measure in either direction" with respect to the deficit).

${ }^{23}$ See, for example, Joseph White and Aaron B. Wildavsky, The Deficit and the Public Interest: The Search for Responsible Budgeting in the 1980s 488 (California 1989) (quoting Senator Pryor, who said that the addition of this requirement was "the critical moment in this bill. After that, it was a totally different game."). See also Edward M. Gramlich, U.S. Federal Budget Deficits and Gramm-Rudman-Hollings, 80 Am Econ Rev 75, 80 (1989) ("Rather than permitting legislators to compete in giving away tax benefits, the GRH rules enforced in the bargaining on [the Tax Reform Act] forced all giveaway amendments to be deficit neutral, which took all the fun out of giveaways.").

${ }^{2}$ See Stith, 76 Cal L Rev at 634 (cited in note 24) (" $[$ P]olitical unease about the deficit, which intensified as deficits grew during the 1970s and early 1980s, may have made GRH ... inevitable."). Although this process of codifying informal norms occurs in many areas, it is particularly important in the federal budget process, in which Congress has been forced to adapt to evolving political and fiscal imperatives. See Schick, Capacity to Budget at 85 (cited in note 23). See also David C. King, Turf Wars: How Congressional Committees 
codified the norm of revenue neutrality and extended it to new direct spending programs. PAYGO is the primary method used in the 1990 Budget Enforcement Act ${ }^{30}$ to bring the "automatic" portion of the budget-taxes and entitlement programs (which are not subject to the annual appropriations process, but are instead "permanently" appropriated)—within the scope of the budget process. The goal of PAYGO is not to reduce the deficit, to decrease spending for established entitlement programs, or to minimize revenue loss from existing tax expenditures. Rather, PAYGO aims to ensure that new legislation will not increase the deficit. In other words, if spending for an existing entitlement program increases because more persons qualify for it or because benefits are automatically adjusted to account for a higher cost of living, PAYGO is not triggered. Similarly, if revenue losses from previously enacted tax expenditures exceed expectations because more taxpayers claim them, no budget rule requires Congress to find an offset. However, if higher spending results from new entitlement programs, new tax expenditures, or new laws that expand existing programs, PAYGO applies.

Under PAYGO, "direct spending and revenue legislation that increases the deficit in any fiscal year ... must be offset by legislation reducing spending or increasing revenues so that the net deficit is not increased." ${ }^{\prime 31}$ Unlike the earlier revenue neutrality norm, PAYGO does not require that each bill be revenue neutral; instead, revenue-losing bills can be offset by other legislation in a particular fiscal year. Some legislation that would otherwise fall under the PAYGO rules is exempt, including legislation that the President and both houses of Congress designate as an emergency. ${ }^{32}$ Otherwise, PAYGO applies broadly and indiscriminately to all revenue and entitlement laws, including legislation enacting additional tax expenditures, broad-based tax relief bills, and proposals to restructure the tax code. The Office of Management and Budget keeps a running total of these complicated calcula-

Claim Jurisdiction 59 (Chicago 1997) (arguing that much congressional reform consists of adopting formal rule changes that mirror institutional changes that have evolved over time much as the common law does).

${ }^{30}$ The Budget Enforcement Act of 1990 was a small part of a larger budget agreement that attempted to reduce the deficit by approximately $\$ 500$ billion over five years through spending cuts and tax increases. See generally Shuman, Politics and the Budget at 311-35 (cited in note 9) (detailing process).

${ }^{31}$ Edward Davis, "Pay-As-You-Go" Budget Enforcement Procedures in 1992, CRS Order Code IB92055, preface (1993). See GRH § 252.

${ }^{32}$ GRH \& 252(e). See Elizabeth Garrett, Enhancing the Political Safeguards of Federalism? The Unfunded Mandates Reform Act of 1995, 45 U Kan L Rev 1113, 1141-42 (1997) (discussing the exceptions for emergencies and the political nature of that determination). 
tions as a running total on the "PAYGO scorecard. ${ }^{\text {"33 }}$ If Congress does not offset any revenue loss in a particular fiscal year by either increasing taxes or reducing entitlement spending, funds are sequestered (automatically and uniformly cut) from certain direct spending programs to make up the difference. ${ }^{34}$

PAYGO differs in another important way from the norm governing the consideration of the 1986 Tax Reform Act. In that Act, revenue for lower tax rates and new tax expenditures had to be found in the tax code. PAYGO, on the other hand, allows Congress to offset tax decreases with cuts in entitlement spending; ${ }^{35}$ it does not limit Congress to raising taxes to achieve revenue neutrality. Certain consequences of this flexibility have not been apparent until recently because Congress did not rely heavily on entitlement cuts to fund tax reductions. The 1990 and 1993 omnibus budget reconciliation bills actually raised revenue for deficit reduction, and smaller bills since PAYGO's adoption met offset requirements primarily by paying for tax subsidies with changes within the tax code. But in 1997, the Taxpayer Relief Act, ${ }^{36}$ which parceled out new tax subsidies worth hundreds of billions of dollars, satisfied PAYGO in large part by matching revenue loss with direct spending cuts, primarily in Medicare. ${ }^{37}$ As Congress reduces Medicare spending to avert insolvency in the next few years, the use of direct spending offsets may increase; ${ }^{38}$ under

ss See Davis, "Pay-As-You-Go" in 1992 at CRS 8 (cited in note 31), for an example of a PAYGO scorecard. Absent congressional action, excess deficit reductions can be carried over to offset revenue losses in subsequent years.

${ }^{34}$ Most entitlement spending is exempt from a sequester. For example, Social Security, net interest, veterans' compensation and pensions, federal retirement and disability benefits, and the Postal Service are exempt. Medicare is limited to no more than a 4 percent reduction. GRH $\$ \S 252(c)(1), 255$. Moreover, tax expenditures are not considered spending for this purpose, so they are effectively exempt from the threat. Thus, any sequester would fall heavily on the few direct spending programs remaining, which in 1996 represented only about $\$ 30$ billion to $\$ 35$ billion of all such spending. See Stanley E. Collender, The Guide to the Federal Budget Fiscal: 199729 (Rowman \& Littlefield 1996).

${ }^{35}$ In the budget context, reductions in federal spending may or may not be absolute reductions from the previous year's levels. In most cases, reductions are from the current services baseline, which measures what it would cost in the future to provide the services the government provides today. See Timothy J. Muris, The Uses and Abuses of Budget Baselines, in John F. Cogan, Timothy J. Muris, and Allen Schick, eds, The Budget Puzzle: Understanding Federal Spending 41, 43 (Stanford 1994) (also defining current law and current policy baselines).

3 Pub L No 105-34, 111 Stat 789, codified at numerous sections of 26 USCA (Supp 1997).

"See Richard W. Stevenson, Conflicting Views Put Republicans in a Bind on Cutting Taxes, NY Times A36 (June 8, 1997) (Only $\$ 50$ billion of the $\$ 135$ billion proposed tax cut will be paid for by new tax revenue.).

33 The trust fund for the portion of Medicare that covers hospital insurance (Part A) is projected to be insolvent by 2001. See Bipartisan Commission on Entitlement and Tax Reform, Interim Report to the President 16 (GPO 1994); Marilyn Werber Serafini, Medicare: 
PAYGO accounting, unless Congress adopts some sort of mechanism to remove the funds from the scorecard, any revenue saved by restructuring entitlement programs can be "spent" on new tax cuts. ${ }^{39}$ Certainly, the Taxpayer Relief Act marks a new direction for PAYGO that may lead policymakers to consider whether they want to change the budget rules so that savings from entitlement reform cannot fund new tax expenditures. ${ }^{40}$

The norm of revenue neutrality also appears in two other budget rules that affect tax legislation. Annual congressional budget resolutions usually contain one or more reserve funds that allow the Senate to pass revenue and/or direct spending legislation for enumerated purposes so long as this legislation does not increase the deficit in the first fiscal year covered by the budget resolution, the five year period covered by the budget resolution, and the next five fiscal years. ${ }^{41}$ Reserve funds provide the Senate Finance Committee some flexibility to consider revenue neutral tax legislation that is only generally anticipated when Congress considers the budget resolution. ${ }^{42}$ The Senate enforces reserve fund provisions through parliamentary procedure. If a bill violates any of the three revenue neutrality requirements, a senator can raise a substantive point of order to prevent its consideration. After debate, the Senate votes whether to sustain or waive the point of order. Under the Budget Act, the objection can only be waived by a vote of three-fifths of all the senators (sixty votes, if there are no vacancies). ${ }^{43}$ Thus, unlike the PAYGO requirement,

Round Two, Natl J 2632 (Dec 7, 1996). A national commission will report to Congress at the end of 1998 with reform proposals to ensure financial viability. Marilyn Werber Serafini, Taking a Look Into Medicare's Future, Natl J 1638 (Aug 16, 1997).

${ }^{30}$ For example, the 104th Congress removed $\$ 6.2$ billion from the PAYGO balance so that it would not be available to offset revenue losses in future legislation and would be applied to deficit reduction. See Omnibus Consolidated Appropriations Act of $1997 \$ \S 101$ et seq, Pub L No 104-208, 110 Stat 3009, codified at numerous USC Titles.

${ }^{40}$ But see Concurrent Resolution on the Budget for Fiscal Year 1998 \& 336, H Con Res 84, 105th Cong, 1st Sess, in 143 Cong Rec E1134 (June 5, 1997) (providing "Sense of the Senate," see note 158, that nothing should prohibit Congress from providing further tax cuts that are offset by spending reductions or additional revenue).

"See, for example, Concurrent Resolution on the Budget for Fiscal Year 1996 $\S 203(a)(1)(3), H$ Con Res 67, 104th Cong, 1st Sess, 109 Stat 996 (June 29, 1995). Typically, reserve funds for tax legislation double the period of the relevant budget "window" past the five year perspective required of budget resolutions. Compare id with Section 606 of the Budget Act. Because the 1997 Taxpayer Relief Act enacted a net tax cut (paid for by reductions in direct spending), the fiscal year 1998 budget resolution did not contain a reserve fund for tax legislation, although it did provide for one that would have allowed deficit neutral surface transportation legislation. See $H$ Con Res 84 \$ 210.

4 See Collender, Guide to the Federal Budget: Fiscal 1997 at 55-56 (cited in note 34).

${ }^{4}$ See Garrett, $45 \mathrm{U}$ Kan L Rev at 1161 (cited in note 32) (contrasting substantive points of order in the budget process with the parliamentary devices used generally to enforce congressional rules). The budget process is characterized by supermajority voting re- 
the pay-as-you-go provision in the Senate applies only within individual bills and is enforced through a parliamentary device, rather than through sequestering funds. Although the reserve fund provisions apply only in the Senate, constraints on Senate deliberations indirectly constrain the House, which in most cases will be unwilling to pass legislation that will be out of order in the Senate.

Finally, Section 311(a) of the Budget Act prohibits amendments to a budget reconciliation act if they "would cause revenues to be less than the appropriate level of total revenues set forth in

quirements in the Senate that provide enforcement for a number of rules, some of them amazingly arcane. See, for example, Charles Tiefer, Congressional Practice and Procedure: A Reference, Research, and Legislative Guide 908-14 (Greenwood 1989) (describing basic points of order). The increasing use of supermajority voting requirements to make certain legislative outcomes more difficult to enact has begun to elicit academic commentary. For example, questions concerning the wisdom and constitutionality of the recent House rule requiring a three-fifths vote to raise federal tax rates have sparked debate. See Bruce Ackerman, et al, An Open Letter to Congressman Gingrich, 104 Yale L J 1539 (1995) (criticizing the rule); John O. McGinnis and Michael B. Rappaport, The Constitutionality of Legislative Supermajority Requirements: A Defense, 105 Yale L J 483 (1995) (criticizing Ackerman and supporting the rule); Jed Rubenfeld, Rights of Passage: Majority Rule in Congress, 46 Duke L J 73 (1996) (criticizing McGinnis, Rappaport, and the rule). Others have questioned the ability of one Congress to entrench its policy preferences and to reduce the options available to future legislative majorities. See Catherine Fisk and Erwin Chemerinsky, The Filibuster, 49 Stan L Rev 181, 248 (1997) ("[T]he [Supreme] Court has expressed the same view that it is unconstitutional for a legislature to bind its successors."); Julian N. Eule, Temporal Limits on the Legislative Mandate: Entrenchment and Retroactivity, 1987 Am Bar Found Res J 379 (1987); Paul W. Kahn, Gramm-Rudman and the Capacity of Congress to Control the Future, 13 Hastings Const L Q 185, 188 (1986) (arguing that "[t]he kind of control of the legislative function that [GRH] intends can only be accomplished constitutionally through the amendment process, not by statute"). But see Lynn A. Baker and Samuel H. Dinkin, The Senate: An Institution Whose Time has Gone?, $8 \mathrm{~J} \mathrm{~L}$ \& Pol 21, 56 (1997) (discussing use of supermajority voting in Senate to counter structural problems of representation, such as the bias in favor of less populated states). A consideration of this literature is beyond the scope of this Article. It is worthwhile, however, to offer two brief comments here. First, in the budget context, supermajority requirements and other institutionalized structures can operate as precommitment devices to avoid collective action problems that reduce Congress's ability to achieve preferred policy outcomes. See Garrett, 45 U Kan L Rev at 1132-33 (cited in note 32); Saul Levmore, Precommitment Politics, 82 Va L Rev 567 (1996). Of course, they can also block desired shifts in policy. Second, Professor Klarman distinguishes between a "majoritarian precommitment," which allows "today's majority to bind itself against future temptations," and "cross-temporal entrenchment," which involves "today's majority seeking to control future majorities." Michael J. Klarman, Majoritarian Judicial Review: The Entrenchment Problem, 85 Georgetown L J 491, 507 (1997). Majoritarian precommitment is less problematic for all those who have studied entrenchment (although Klarman's distinction may be difficult to make in practice because any law lacking a sunset provision has elements of both). Both the ability of a simple majority to alter budget rules (including supermajority requirements) and the frequent amendments to the budget acts suggest that budget rules are majoritarian precommitment devices, not cross-temporal entrenchments. But see Kahn, 13 Hastings Const $L Q$ at 188 (arguing that GRH is an impermissible crosstemporal entrenchment). 
such concurrent resolution. ${ }^{\$ 44}$ Congress uses the reconciliation process to enact revenue and direct spending laws that are needed to meet the goals of the concurrent budget resolution. Congressional budget resolutions, which are concurrent resolutions without the force of law, ${ }^{45}$ reveal only Congress's macrobudgetary goals; they provide aggregate figures, leaving to the substantive committees the responsibility and the power to fill in the details. For actual savings to occur in the entitlement or revenue arenas, Congress must consider and pass reconciliation legislation, which adjusts tax laws and mandatory spending to accord with the instructions in the budget resolutions. Since the mid-1980s, Congress has used omnibus reconciliation acts as the legislative vehicles to implement the deficit reduction plans set forth in the budget resolutions, including the 105th Congress's legislation to balance the budget by $2002 .{ }^{46}$ Section 311(a) effectively requires that any amendment to a reconciliation bill be revenue neutral, thereby limiting the ability of members to amend reconciliation legislation on the floor. Unlike PAYGO, the offset cannot come from reducing entitlement spending. As with reserve fund limitations, the Senate can waive this requirement only by a three-fifths vote; Section 311(a) also applies to amendments in the House, which can waive it in a special rule or by majority vote. ${ }^{47}$

\section{OFFSET REQUIREMENTS REDUCE THE LEVEL OF NEW FEDERAL SPENDING}

The various pay-as-you-go rules reinforce the zero-sum character of modern budgeting as a tool to force legislators to reduce the amount of new federal spending. ${ }^{48}$ More specifically with re-

4 2 USC $\$ 642(a)(1)(1994)$.

${ }^{45}$ See Floyd M. Riddick, Riddick's Senate Procedure: Precedents and Practices 442 (GPO 1992) (defining concurrent resolutions).

${ }^{46}$ See, for example, Balanced Budget Enforcement Act of 1997, HR 898, 105th Cong, 1st Sess (Feb 27, 1997).

${ }^{47}$ See Garrett, 45 U Kan L Rev at 1163 (cited in note 32) (detailing waiver by special rule in the House). The House has waived budget points of order over six hundred times since the 1974 Budget Act became effective. See also How Did We Get Here From There: Reform of the Federal Budget Process, Hearings Before the House Committee on the Budget, 104th Cong, 2d Sess 93 (1996) (prepared statement of Representative Charles W. Stenholm).

48 PAYGO and other similar provisions directly affect only proposals for new tax expenditures and new entitlement spending and thus appear to leave the status quo unchanged. See Penner and Abramson, Broken Purse Strings at 33 (cited in note 23); Wildavsky and Caiden, New Politics at 150 (cited in note 8). However, as I will explain in Part III, an offset requirement indirectly causes review of existing provisions, as a byproduct of efforts to enact new programs. 
gard to tax legislation, offset requirements, and the interest group competition they foster, increase the costs of enacting new tax expenditures at the same time that they decrease the value of tax subsidies. After we understand precisely how PAYGO and the other rules work to reduce the amount of new federal spending through the tax code (and in entitlement legislation), we will consider the puzzle of why legislators implemented such a framework.

\section{A. PAYGO Increases the Cost of Enacting New Tax Expenditures}

Offset requirements force those seeking federal benefits to undertake an additional role; not only are they funding seekers, but they must also become funding predators. ${ }^{49}$ To receive funding for any new program, groups must first advocate eliminating or reducing an existing one; they can no longer rely on deficit financing to push the costs into the future. One straightforward funding option is to raise money through higher tax rates. Congress, however, rarely does this-at least not openly-because lawmakers believe, with reason, that a decision to raise taxes will hurt them at the polls. ${ }^{50}$ While the public may be generally inattentive to lawmakers' actions in Washington, a challenger can use higher taxes to rouse the inattentive on election day. The Democrats and President Clinton learned this lesson in 1994 when the Republican Party and its candidates used the issue of tax increases to capture the House and Senate. ${ }^{51}$ Furthermore, it

49 I am grateful to AL Jones-Hartsough for this phrasing.

${ }^{50}$ See R. Douglas Arnold, The Logic of Congressional Action 193-94 (Yale 1990) (noting that "legislators fear electoral retribution" when they raise taxes, and that the fear is justifiable because direct taxes "impose perceptible costs on those who pay them; the costs can be traced to identifiable governmental actions ...; and legislators are required to take public positions on most tax bills"). See also Schick, Capacity to Budget at 145 (cited in note 23) (Even as early as 1980 , Congress preferred to use "revenue enhancements" rather than rate increases to meet deficit reduction targets.); Shapiro, Complexity in the Tax Legislative Process at I-J-32 (cited in note 14) ("DD]uring the $1980 \mathrm{~s}, \ldots$ revenue increases have been a large part of the overall deficit reduction ... because revenue increases in the form of 'base broadeners,' 'loophole closers,' user fees, or tax changes of limited applicability have not been perceived by the general public as tax increases.").

${ }^{31}$ See Arnold, Logic of Congressional Action at 68-71 (discussing the concept of the inattentive public and the ability of challengers, political parties, or other entrepreneurs to instigate action with respect to a policy that imposes direct burdens on it); David S. Broder, Vote May Signal GOP Return as Dominant Party; Victors Push Beyond Solid Southern Base, Wash Post A1 (Nov 10, 1994) ("The driving force for all the Republican gains ... was the voters' identification of Clinton and the Democratic Party with big government and higher taxes. Try as he might to convince voters that he represented a different kind of approach, the upper-bracket tax hike in his 1993 budget plan and the scope of his failed health reform convinced people that Clinton was not the New Democrat he had sketched 
may have become more difficult to increase tax rates since the 1995 enactment of a House rule requiring a three-fifths vote to pass such legislation. ${ }^{52}$

Congress thus seldom enacts blatant tax hikes. It is more likely, instead, to pass less transparent forms of broad-based tax increases. The beauty of bracket creep (from a lawmaker's perspective) was that it allowed taxes to increase without any congressional action. ${ }^{53} \mathrm{It}$, along with deficit financing, provided lawmakers with fiscal illusions that masked both higher tax burdens and legislators' responsibility for them. Members now use complicated tax provisions, such as the overall limitation on itemized deductions ${ }^{54}$ or the phase-out of the personal exemption, ${ }^{55}$ to disguise tax rate hikes and minimize negative voter reaction.

Because of the political taboo associated with tax increases, the tax legislative process is presently dominated by the quest to find a different sort of offset. This search significantly raises the cost of obtaining a benefit. Although groups can approach Congress for benefits without also presenting a way to pay for their new spending, success is more likely if they have a revenue neutral package. ${ }^{56}$ Moreover, if the benefit is proposed as an amend-

in his 1992 campaign speeches."); Donald Lambro, GOP Candidates Ride on Tax-Cut Rhetoric; Economic Growth Rules Governor Races, Wash Times A1 (Oct 7, 1994) ("According to polls, GOP candidates running on tax cuts . . . were well ahead."). The 1993 Act added a new marginal tax rate of 36 percent and a surtax on the rich that was essentially a top marginal tax rate of 39.6 percent. Omnibus Budget Reconciliation Act of 1993 (“OBRA 1993") §§ 13201-02, Pub L No 103-66, 107 Stat 312, 457-61, codified at 26 USC § 1 (1994). Voters were unmoved by the fact that the higher rates affected only 1.4 million taxpayers, Treasury Department, Estimated Distribution Across Congressional Districts of Taxpayers Facing Higher Rates and Earned Income Tax Credit Recipients (1993), reprinted in Tax Notes Today Doc 93-12955 (Dec 15, 1993), and by President Clinton's effort, by creating a deficit reduction fund, to convince them that the revenues would go to deficit reduction rather than new programs, Exec Order 12858 (Aug 4, 1993), in 3 CFR 626 (1994).

${ }^{52}$ Rule of the House XXI, cl 5(c), H Res 5, 105th Cong, 1st Sess (Jan 7, 1997), in 143 Cong Rec H 9 (Jan 7, 1997). See also note 43 (discussing constitutionality of such provisions). This rule appears not to be a significant hurdle, however, because Congress can easily waive it. See Skaggs $v$ Carle, 110 F3d 831, 835 (DC Cir 1997) (listing at least four times in the 104th Congress that the rule was waived by simple majority vote).

${ }^{53}$ See Timothy J. Conlan, Margaret T. Wrightson, and David R. Beam, Taxing Choices: The Politics of Tax Reform 19 (CQ 1990) (terming bracket creep as "a fiscal and political gold mine" for legislators).

${ }^{54}$ Internal Revenue Code ("IRC") § 68, codified at 26 USC § 68 (1994).

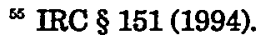

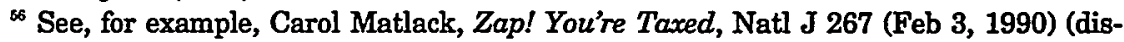
cussing lobbyist (who is now the Chief of Staff of the Joint Tax Committee) who "knew that his chances of prevailing [on a proposed tax expenditure] would be greatly enhanced if he came up with a revenue-raising measure"); Joyce, 56 Pub Admin Rev at 321 (cited in note 22) ("Since the BEA was enacted, ... explicit assumptions of deficit neutrality (PAYGO) ha[ve] made the question, How will you pay for it?' the first one asked of proponents of costly new spending."). But see Matlack, Natl $J$ at 269 (mentioning another lob- 
ment in committee or on the floor of Congress, an offset may be required to meet the revenue neutrality requirements necessary to avoid a point of order. ${ }^{57}$ Advocates therefore must invest resources in identifying a promising offset. Some information about possible targets is public and easily obtainable. For example, one of the lasting consequences of the Budget Act is a requirement that Congress and the executive branch produce lists of tax expenditures with estimates of the revenue losses attributable to them. ${ }^{58}$ Interest groups comb these lists, paying special attention to upward revisions in revenue estimates. ${ }^{59}$

byist who indicated that no member had asked him for an offset and questioned whether such a process was consistent with "good public policy"). Supporters of tax benefits that lose only a small amount of revenue need not produce offsets if they have strong advocates on the tax writing committees. To ensure that members will support the chairman's bill in committee, it is common practice to include in the mark a number of very targeted benefits that are paid for by other revenue-raising provisions inserted by the committee leader\$hip. See Gene Steuerle, Whatever Happened to Equal Justice?, Tax Notes 119, 120 (July 7, 1997). The recently enacted Line Item Veto Act, which allows the President to cancel targeted tax benefits, may undermine the ability of chairmen to offer such deals. See Pub L No 104-130 § 1021(a)(3), 110 Stat 1200 (1996), codified at 2 USCA § 691 (1997).

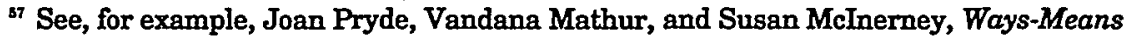
Continues Tax Markup, Defeats Wide Range of Amendments, Daily Tax Rep G-9, G-10 to G-11 (June 13, 1997) (listing amendments offered in committee and the offsets that accompanied them). See also id (describing the failure of a politically popular amendment to eliminate the real estate depreciation recapture provision because it was paired with an unpopular revenue-raiser, the elimination of the proposed reduction in the corporate capital gains rate).

${ }_{\mathrm{Bs}}$ See, for example, Budget Act $\S 308$, codified as amended at 2 USC $\S 639 ;$ Budget of the United States Government for Fiscal Year 1998, Analytical Perspectives, H Doc 105003, 105th Cong, 1st Sess, ch 5 (1997); Joint Committee on Taxation, Estimates of Federal Tax Expenditures for Fiscal Years 1997-2001 (Nov 26, 1996); Senate Committee on the Budget, Tax Expenditures: Compendium of Background Materials on Individual Provisions, 104th Cong, 2d Sess, S Prt 104-69 (GPO 1996).

so See Martin A. Sullivan, Budget Reveals Significant Changes in Tax Expenditure Estimates, Tax Notes 1473 (Mar 17, 1997) ("In the calculus of budget politics, the benefits of repeal (i.e., the estimated revenue saving that may be available for other programs) have increased while the political costs (the opposition of interest groups) remain the same. Conversely, a lower tax expenditure estimate diminishes the likelihood of its repeal."). Sullivan's observation is only half right in many instances; if the existing tax provision provides a more valuable benefit, perhaps because tax rates have increased, then the strength of the opposition to its elimination may well be greater. If the revenue estimate has changed only because the estimators have better information, then his statement that the political cost remains the same is accurate. The importance of these estimates to interest groups' strategies with regard to offsets underscores the political importance of the technical staff in the legislative and executive branches. Commentators should pay more attention to the staffs' role in the formulation of tax policy and to the politicization of superficially neutral decisions. See Linda A. Schwartzstein, Smoke and Mirrors: Tax Legislation, Uncertainty and Entrepreneurship, 6 Cornell J L \& Pub Pol 61, 77-83 (1997) (discussing method and limitations of revenue estimating); Garrett, $45 \mathrm{U}$ Kan L Rev at $1162 \mathrm{n}$ 211 (cited in note 32) (discussing importance of the CBO's role in another part of the budget process, the application of the Unfunded Mandates Reform Act); Michael J. Graetz, Paint-By-Numbers Tax Lawmaking, 95 Colum L Rev 609, 681-82 (1995) (discussing evidence that distributional tables produced by Joint Committee on Tax and Treasury are 
Other political actors also produce sources for offsets. The Congressional Budget Office (“CBO") publishes an annual report, Reducing the Deficit: Spending and Revenue Options; ${ }^{60}$ administration officials sometimes release (or leak) documents that contain suggestions for changes to the tax code that will raise money. ${ }^{61}$ Public interest organizations and think tanks also produce documents that can be scoured for offsets, ${ }^{62}$ and boutique Washington firms specialize in identifying and drafting suitable offsets for those seeking new tax subsidies. ${ }^{63}$ Groups may publicize negative aspects of tax subsidies that benefit their competitors either to level the playing field or to gain a competitive advantage. Of course, not all the provisions found through such sources will serve as offsets. The tax expenditures that represent the greatest revenue loss for the federal government are virtually untouchable: the home mortgage interest deduction, preferential treatment for retirement savings and employer-provided health benefits, and the stepped-up basis of capital assets at death. ${ }^{64}$

driven by politics rather than economic science); Michael D. Bopp, The Roles of Revenue Estimation and Scoring in the Federal Budget Process, Tax Notes 1629 (Sept 21, 1992) (discussing increasing political pressures on revenue estimators since PAYGO's passage). See also Shuman, Politics and the Budget at 284 (cited in note 9) (recounting CBO Director Penner's criticism that GRH gave "an excessive amount of power to appointed officials such as himself").

${ }^{\infty}$ For the latest report, see Reducing the Deficit: Spending and Revenue Options (CBO 1997). See also Lawrence J. Haas, Protection Squad, Natl J 1270, 1273-74 (May 26, 1990) (discussing role of Joint Tax staff in suggesting options); Harold R. Handler, Budget Reconciliation and the Tax Law: Legislative History or Legislative Hysteria?, Tax Notes 1259, 1266 (Dec 21, 1987) (same).

${ }^{61}$ See, for example, Budget of the United States Government for Fiscal Year 1997, Analytical Perspectives ch 3 (GPO 1996); Message from the President about his Budget Proposals, H Doc 104-160, pt 1, 104th Cong, 2d Sess 10-12 (1996) (containing revenue estimates); Draft Memorandum Prepared by Alice Rivlin, Director of Office of Management and Budget, on Options for Administration's FY 1996 Budget, Dated Oct. 3, 1994, Daily Tax Rep I-1 (Oct 25, 1994).

* See, for example, Dean Stansel and Stephen Moore, Briefing Paper, Federal Aid to Dependent Corporations: Clinton and Congress Fail to Eliminate Business Subsidies (Cato, May 1, 1997); Robert J. Shapiro and Chris J. Soares, Cut and Invest to Grow: How to Expand Public Investment While Cutting the Deficit (Progressive Policy 1997); Tax Loopholes From A to Z: The Comprehensive Compendium (Citizens for Tax Justice, May 2, 1996).

* See, for example, Letter from Alvin Brown, Tax Legislative Services, to Dan Webber, Legislative Director to Senator David L. Boren (Aug 15, 1992) (on file with U Chi L Rev) ("I like to draft compliance rules and legislation that close tax loopholes. ... If Senator Boren would like to help a constituent who wants a floor amendment to H.R. 11 [a tax bill vetoed by President Bush], and you cannot get the assistance you need from Finance staff or Joint Tax, I have an inventory of some quality virgin (never used) raisers.' . . . I love doing the raisers as a matter of principle, and I would enjoy being of some help to any of your constituents.").

${ }^{64}$ See Budget of the United States Government Fiscal Year 1998, $2 \mathrm{H}$ Doc 105-003 at 79 table 5-3 (cited in note 58) (listing major tax expenditures in the income tax ranked by 
Selecting an appropriate offset from these sources involves several determinations; one of the most important is whether other interest groups will strongly defend the potential offset. One way to avoid vigorous opposition is to choose a provision that benefits the relatively needy, rather than an expenditure that benefits organized and wealthy economic interests. ${ }^{65}$ The former are likely to be more dispersed and less able to organize; even if members do mount some opposition, a well-financed funding predator may more likely prevail against such groups than if it targets a provision defended by organized and wealthy beneficiaries.

Again, however, several political realities limit the availability of this offset strategy. First, such tax provisions, sometimes called need-based provisions ${ }^{66}$ have their supporters in and out of Congress. Because of their ideological commitments or a desire to influence public policy, lawmakers or party activists sometimes act as policy entrepreneurs, representing the interests of the unorganized or disadvantaged. Professors Schlozman and Tierney define a policy entrepreneur as someone "who, through adroit use of the media, can mobilize public support by appealing to widely shared values such as a concern about health, safety, or environmental preservation and by making opponents seem self-serving and careless of the public interest. ${ }^{267}$ Moreover, even though smaller groups are more likely to organize in an attempt to influence the government, ${ }^{68}$ groups representing large numbers of persons concerned with issues of broad importance do form and work to influence federal policy. ${ }^{69}$ Therefore, those seeking a new pro-

total revenue loss).

${ }^{\infty}$ See, for example, Graham K. Wilson, Interest Groups 75 (Basil Blackwell 1990) ("The budget cuts of 1981 were shaped in such a way as to impose the greatest burdens on those, such as the poor, with the least political power and to avoid interests, such as the elderly or aircraft manufacturers, with strong interest groups.").

os John F. Witte, in his excellent analysis of tax expenditures, classifies them as falling into the first of his five categories: need-based; tax equity; special group; general economic; and specific economic. John F. Witte, The Politics and Development of the Federal Income Tax 273-75 (Wisconsin 1985).

" Kay Lehman Schlozman and John T. Tierney, Organized Interests and American Democracy 84 (Harper \& Row 1986). See also id at 402 (stating that the poorly represented in the pressure community receive attention because of policy entrepreneurs); Daniel Shaviro, Beyond Public Choice and Public Interest: A Study of the Legislative Process as Mlustrated by Tax Legislation in the 1980s, 139 U Pa L Rev 1, 93-94 (1990) (discussing the role of policy entrepreneurs in the enactment of the 1986 Tax Reform Act). But see Garrett, 81 Cornell L Rev at 660-62 (cited in note 7) (unpacking varied motivations of legislators).

* See generally Mancur Olson, The Logic of Collective Action: Public Goods and the Theory of Groups (Harvard 1965).

- See Schlozman and Tierney, Organized Interests at 74 (noting that one of the most 
gram cannot be guaranteed that a need-based offset will produce inadequate opposition.

Second, distributional concerns operate to provide some level of protection for current provisions that benefit lower-income Americans. In addition to imposing the norm of revenue neutrality on the Tax Reform Act of 1986, drafters agreed that the bill should be distributionally neutral as well. ${ }^{70}$ In other words, the bill should not change the relative tax burden borne by the various income classes of individual taxpayers. Recent significant tax laws, the reconciliation bills of 1990 and 1993, were designed to be progressive in their distributional effects, a goal that powerfully protected need-based provisions. ${ }^{71}$ Although such distributional constraints are not formally binding through any budget rule or procedure, legislators know that distributional effects are politically important. They do not draft modern tax bills without considering them. Regardless of which party is in the majority, no Congress is likely to eliminate or reduce provisions that benefit lower-income taxpayers in order to provide tax expenditures for businesses or higher-income Americans. Even in the debate over the Taxpayer Relief Act of 1997, a bill not characterized by a concern about progressivity, distributional concerns were still discussed prominently. ${ }^{72}$ However, because changes in entitlement

important changes in Washington politics since the mid-1960s has been the emergence of "many new groups-ranging from Common Cause and Ralph Nader's Public Citizen to the National Urban Coalition and the Migrant Legal Action Project-representing broad publics and the less advantaged"); Wilson, Interest Groups at 49-50 (cited in note 65) (noting that since the 1970s, "a wide range of interest groups had developed representing precisely those interests which political scientists had predicted would be the most difficult to organize"). See also Marci A. Hamilton, Discussion and Decisions: A Proposal to Replace the Myth of Self-Rule with an Attorneyship Model of Representation, 69 NYU L Rev 477, 535 (1994) (discussing the role of legislators in representing interests that might not be heard in the political process and describing it as a sort of "best-world model of representation").

${ }^{70}$ Michael J. Graetz, The Truth About Tax Reform, 40 U Fla L Rev 617, 624-25 (1988).

${ }^{11}$ Graetz, 95 Colum L Rev at 612 (cited in note 59).

${ }^{72}$ See J.D. Foster, Income and the Art of Tax Distribution Analysis, Tax Found Extra Point 1 (Aug 1, 1997); Clay Chandler, The Tax Gap, Wash Post 13 (July 14, 1997) (weekly ed) (Secretary Rubin criticized Republican bills as unfair because insufficiently progressive.); John Godfrey, Night and Day: GOP, Dems Fight Over Distribution Tables, Tax Notes 10 (July 7, 1997). The importance of distributional analysis in the modern tax legislative process was underscored when the Joint Tax Committee released a description and defense of its methodology. Joint Committee on Taxation, Methodology and Issues in Measuring Changes in the Distribution of Tax Burdens (GPO 1993). See also Godfrey, Tax Notes at 10 (noting that the Joint Tax Committee recently changed the measure of income used for distributional tables, a move some characterize as politically driven). See generally David F. Bradford, ed, Distributional Analysis of Tax Policy (AEI 1995). Compare Vandana Mathur, Hill Proposals to Use Budget Surplus for Tax Cuts Called Regressive* by Raines, Daily Tax Rep G-2 (Sept 16, 1997) (OMB Director attacking on distributional grounds a proposal to use budget surplus for tax cuts.). 
programs are not included in distributional tables prepared by the Joint Tax Committee or Treasury, need-based entitlement programs may not enjoy the political insulation afforded by the preoccupation with distributional effects. Need-based entitlement programs therefore may be more likely targets for offsets than similar need-based programs implemented through the tax code.

If political considerations largely rule out increasing tax rates or reducing need-based tax expenditures, advocates of new provisions must resort to targeting other tax expenditures, which are often supported by other organized groups. ${ }^{73}$ Where conflict ensues, the group protecting the existing tax expenditure is likely to defeat the group proposing it as an offset, even if the latter has worked diligently to find a provision supported by a relatively less powerful or less well-organized group.

First, it can be difficult to discover which and how many interest groups are concerned about a particular benefit, so an offset proposal may provoke unexpectedly strong opposition. Not only are taxpayers who directly claim the tax expenditure likely to object to its reduction or repeal, but service providers or related industries may also emerge as powerful opponents. As Professor Howard observes generally: "[T]ax expenditures rely almost exclusively on third parties in the private sector for service delivery [that] expands the number of beneficiaries and strengthens the base of interest-group support for each program."74 For example, perhaps the most vociferous supporters of the targeted jobs tax credit ${ }^{75}$ were not the disadvantaged groups covered by the provision nor the businesses that claimed the credit. Rather, the firms that helped employers determine which employees qualified for the tax credit and complete the necessary tax forms-an industry that would not have existed without the gov-

${ }^{33}$ They can also use accounting gimmicks to speed up the collection of revenue that will be paid under current law so that more money is raised in the budget window. Many predators have relied on timing changes, such as changes in the estimated tax laws, to pay for new tax benefits. See text accompanying notes 97-102. To the extent that tax deferral is valuable for taxpayers, however, requiring them to pay earlier imposes a burden on them. Thus, the analysis of accounting changes is similar to the analysis in the text. If the timing change affects the diffuse group of all taxpayers, then it is a disguised tax rate hike and will be a popular strategy for predators. If the proposed speed-up affects an identifiable group of taxpayers, they will employ the same kind of defensive strategies that I describe later.

" Christopher Howard, Testing the Tools Approach: Tax Expenditures Versus Direct Expenditures, 55 Pub Admin Rev 439, 441 (1995). See Burdett A. Loomis and Allan J. Cigler, Introduction: The Changing Nature of Interest Group Politics, in Allan J. Cigler and Burdett A. Loomis, eds, Interest Group Politics 1, 12 (CQ 3d ed 1991).

${ }^{75}$ IRC $\& 51$ (created in 1978, expired at the end of 1994, and replaced with the work opportunity tax credit). 
ernment program ${ }^{76}$ - were among the most effective lobbyists protecting the credit from elimination.

Second, even if groups seeking to enact a new tax provision precisely target a weak prey, the groups defending the existing provision are in a better position to win. In many cases, those advocating new benefits may be recently organized groups (or fewer groups because service providers will not yet exist) with less clout and experience than established groups that have enjoyed benefits for years. As Robert Reischauer, then Director of the CBO, put it:

[E]xisting programs have one heck of a lot more political support than a program that is a promise in the future. It doesn't have all its interest groups set up yet. It doesn't have a whole set of beneficiaries out there salivating. And so it's a little hard to mobilize the yet-to-be beneficiaries of a program to come and lobby you as opposed to the existing ones who have their offices on $\mathrm{K}$ Street. ${ }^{77}$

Ironically, one of the effects of this dynamic is that current beneficiaries of federal programs are in a better position to gain even more benefits. They already have organized and developed expertise in lobbying the relevant committees. As we will see ${ }^{78}$ in a world of offset requirements, those who receive tax subsidies must remain organized in order to fend off attacks from new funding predators. An organized, established group is more likely to seek new programs than a latent group that must bear the significant start-up costs of organization. ${ }^{79}$ The marginal costs to the former group of agitating for new or increased benefits are much less; thus, the burden of PAYGO is not uniform across groups. This difference may further entrench status quo allocations of government resources.

Third, even if the new program is supported by an established group or coalition, it is generally easier to oppose legislative change than to enact it. The Constitution establishes several

${ }^{76}$ Howard, 55 Pub Admin Rev at 445 (cited in note 74).

"Hearing on a Midcourse Review of the Budget Enforcement Act before the House Budget Committee's Task Force on Budget Process, Reconciliation, and Enforcement, 102d Cong, 1st Sess (Oct 10, 1991). See also Truman, Governmental Process at 353 (cited in note 7); Michael T. Hayes, Lobbyists and Legislators: A Theory of Political Markets 76 (Rutgers 1981).

${ }^{73}$ See Part II.C.

${ }^{7}$ See Robert E. McCormick and Robert D. Tollison, Politicians, Legislation, and the Economy: An Inquiry Into the Interest-Group Theory of Government 17 (Martinus Nijhoff 1981) ("Groups that have already borne these start-up costs, for reasons unrelated to lobbying, will have a comparative advantage in seeking transfers [from the government] and will therefore be more successful in procuring transfers as a result.”). 
impediments to legislative change, such as bicameralism and the presentment requirement, and the Senate and the House have adopted additional hurdles that operate to protect the status quo. ${ }^{80}$ Groups defending an existing tax provision need to prevail at only one stage in the convoluted legislative process. Proponents of the new provision, on the other hand, must successfully navigate all the obstacles. To protect themselves, targets can concentrate on one of the two tax writing committees, or even a few members of the Senate Finance Committee (where the majority party often barely has more seats than the minority), to ensure that the offensive provisions are not included in the mark. Alternatively, they can focus on the administration for help; for example, Ways and Means Chairman Archer's plan to raise billions of dollars by eliminating tax subsidies for ethanol foundered when the Clinton Administration announced strong opposition. ${ }^{81}$ Once the offset appears in the mark, informal committee norms may require the targeted beneficiaries to find their own offset and to present a revenue neutral amendment in order to strike the offending provision. ${ }^{82}$ But if the prey loses at one stage in the process, it can move on to another. ${ }^{83}$ Winning may be more difficult after early losses, but it is still possible; in contrast, a predator must win at each stage.

See Bruce Ian Oppenheimer, Oil and the Congressional Process: The Limits of Symbolic Politics 65 (DC Health 1974) ("The defending side in the legislative process has a major advantage over the initiating side. Prime among these is . . . the 'serial' nature of the legislative process.... [T] winning coalition at each of the many decision making points in the process. The opponents, however, often need only to win at one decision making point to delay, if not defeat, a legislative proposal."). See also Schlozman and Tierney, Organized Interests at 314-15 (cited in note 67).

st See Richard W. Stevenson, Pressured, House Chairman Modifies Tax Plan, NY Times B16 (June 12, 1997). Archer's proposal was significantly scaled back in the Senate version and eliminated by the conference committee (where the administration played a large role).

"A motion merely to strike a provision on the floor of the Senate, however, is not covered by the rule that amendments to reconciliation bills be deficit-neutral. See Budget Act $\$ 310(d)(2)$ (stating that "a motion to strike a provision shall always be in order"). But such an amendment (without an offset) might be vulnerable to a point of order under Budget Act $\$ 311$ (a), which states that an amendment that causes revenues to fall below the level set forth in the budget resolution shall be out of order. And the point of order can be waived only by a three-fifths vote in the Senate. GRH \& 271(b).

* See Barbara Bradley, Tax Cut Lobbying Fever, Natl Public Radio, Morning Edition, Transcript \# 970613090-210 (June 13, 1997) (describing efforts of real estate lobby to defeat a recapture provision; after losing in the Ways and Means Committee, "realtors, like many other interest groups, have moved to the other side of the Capitol to pay visits to members of the Senate Finance Committee"). 
Fourth, prospect theory suggests that groups will work harder to avoid a loss than to gain a benefit. ${ }^{84}$ Leaders of interest groups confirm this, reporting that they can more easily mobilize members to ward off an attack than to mount one.$^{85}$ In part to reduce the chance that other groups will feel threatened, funding predators may try to portray their offset proposal as affecting the same groups of taxpayers that would benefit from the new tax subsidy. For example, the 1993 repeal of the luxury tax on boats was offset in part by a tax on diesel fuel used in noncommercial boats, ${ }^{86}$ and supporters argued that they were paying for their own proposal. If such a characterization is accurate (or is perceived as accurate), then little or no opposing interest group pressure will arise. The problem is that many such characterizations are misleading. For example, the group benefiting from the luxury tax repeal (purchasers and manufacturers of expensive boats) is not entirely congruent with the group paying for the new expenditure (all owners of noncommercial boats who must pay higher fuel prices).

In addition to these costs caused by opposition from target groups, PAYGO also imposes several other costs on groups seeking new tax subsidies. First, even if a group finds a weakly defended target to use as an offset, it has no enforceable property rights in its discovery. ${ }^{87}$ It must be prepared to defend the offset against other predators who might seek to use it to pay for their own new benefits. The system provides no official enforcement mechanism to link a proposed program with the particular offset

see Daniel Kahneman and Amos Tversky, Prospect Theory: An Analysis of Decision Under Risk, 47 Econometrica 263 (1979); Cass R. Sunstein, Behavioral Analysis of Law, $64 \mathrm{U}$ Chi L Rev 1175, 1179-81 (1997); Arnold, Logic of Congressional Action at 32 (cited in note 50) (applying prospect theory to interest group activity with regard to federal benefits). See also W. Mark Crain and Nicole Verrier Crain, Fiscal Consequences of Budget Baselines 5-7 (1996) (unpublished manuscript on file with U Chi L Rev) (applying prospect theory to related context of budget baselines).

${ }^{85}$ See James Q. Wilson, Political Organizations 309 (Basic 1973).

${ }^{86}$ OBRA $1993 \S \S 13161,13163,107$ Stat at 449-53. The diesel fuel tax was repealed in the 1997 bill, Taxpayer Relief Act $\S 902,111$ Stat at 873, but there was neither any discussion of the quid pro quo nature of its enactment nor any suggestion that the price of the excise tax repeal should be reinstatement of the luxury tax on boats. Of course, most offsets cannot be reasonably characterized as burdening only those who benefit from the new programs. See, for example, Lauren Darling and Sindhu G. Hirani, Two Items in Senate Version of Budget Bill Seen Hurting Some Taxpayers, Daily Tax Rep G-9, G-10 (Nov 7, 1995) (discussing proposed increase in the deduction for business meals and entertainment and its offset, which would have repealed Section 1215(c)(5) of the 1986 Tax Reform Act treating Ford Motor Credit as a financial institution for purposes of allocating interest expenses).

${ }^{87}$ See Terry M. Moe, Political Institutions: The Neglected Side of the Story, $6 \mathrm{~J} \mathrm{~L} \mathrm{Econ}$ \& Org 213, 227 (1990) (noting that there are no guaranteed property rights in political arrangements). 
its advocates identify. For example, during the drafting of HR 11, a tax bill vetoed by President Bush, many interest groups revealed their offsets so that their benefits could be included. In the next tax bill, ${ }^{88}$ some of the revenue offsets were included in the chairmen's marks-but without the revenue-losing provisions to which they had been linked. In some cases, the original predator was still able to win its new tax subsidy because a pivotal legislator had the clout to require the recoupling in the final legislation. ${ }^{89}$ In other words, members of Congress can stabilize the rather ephemeral claims predators might have to particular targets. But in the absence of assistance from legislators with leverage, advocates are at risk of losing their investment in developing an offset proposal. Thus, the conflict relevant to my analysis is not limited to the two-way opposition between predator and prey; often many predators circle a promising offset and fight for its revenue. Members of Congress also can be predators because they need to find revenue to pay for tax breaks that they promise their constituents. ${ }^{90}$ All proponents of new programs face these costs, even those who are fortunate enough to find an offset that is not well defended.

PAYGO imposes on predators a second substantial cost that is entirely unrelated to the nature of the target. Current budget procedures make revenue estimates increasingly salient; they play a large role in determining whether a provision can be enacted, as well as whether an existing provision is a promising offset. This translates into a heightened awareness of the cost of new tax expenditures, or at least of the revenue loss within the

* OBRA 1993, 107 Stat at 457.

- For example, in HR 11, the restaurant industry had proposed to pay for a credit for the portion of employer social security taxes paid on employee cash tips by eliminating the deduction under IRC \& 162 allowed to individuals for the payment of club dues. The House version of OBRA 1993 included the disallowance of the club dues deduction, but it did not include the credit for FICA taxes on tips. Because the restaurant industry had a strong ally on the Finance Committee, they were able to recouple the provisions in the final bill. See OBRA $1993 \$ \S 13210,13443,107$ Stat at 469, 568. See also Alissa J. Rubin, Congress' Offset Bind, CQ 1452 (May 25, 1996) (noting that Congress had used several offsets in more than one bill because it was so difficult to find enough revenue to pay for tax bills).

${ }^{\infty}$ See, for example, Helen Dewar, Jumping Aboard the Tax Cut Bandwagon, Wash Post 13, 14 (July 7, 1997) (weekly ed) (Proponents of subsidies for children's health insurance (a direct spending program) used as an offset part of the revenue raised by a cigarette tax, which others on the Finance Committee "had been planning to use for things like relief for real estate interests."); Martin A. Sullivan, Business Versus Business at Ways and Means Markup, Tax Notes 1447, 1447-48 (June 16, 1997) (noting the surprise of many that Chairman Archer used revenue-raisers proposed the year before in the administration's attack on "corporate welfare," but concluding that, "Archer probably made the judgment that sooner or later those revenue-raisers were going to be used by somebody, and so he might as well be the one."). 
budget window for which estimates are provided. ${ }^{91}$ At the same time, this system weakens the fiscal illusion engendered by deficit spending or bracket creep that spending programs are costfree. ${ }^{92}$ In this climate, new federal programs are more difficult to enact. The ability to manipulate revenue estimates, however, allows proponents to mask a great deal of the revenue loss during the early years-a strategy that is also attractive because it reduces the amount of revenue needed for neutrality. It is to such gimmicks and other ways to avoid the costs of the PAYGO system that we now turn our attention.

\section{B. Gimmicks and Downstreaming: Avoiding the High Costs of PAYGO}

The existence of cheaper ways for interest groups to avoid offset requirements decreases the success of PAYGO and similar budget rules at reducing the number of new programs, exploiting interest group conflict, and highlighting the opportunity costs of funding decisions. Several such means of evasion exist, undermining PAYGO's discipline somewhat but not entirely. It is worth identifying and assessing some of them here in order to give a fuller picture of the dynamic effect of budget rules on the legislative process and other parts of the federal government..$^{93}$

${ }^{91}$ Revenue estimates do not completely or accurately indicate the revenue loss of new tax provisions, because the models that estimators use do not fully account for macroeconomic effects. Revenue estimates are sometimes described as "static" by critics, but they do include first-order behavioral responses (that is, changes in the activity level of the behavior that the tax provision directly affects). The Joint Committee on Taxation does not take into account macroeconomic effects, such as changes in total employment, growth in income, and other feedback effects. See Review of Congressional Budget Cost Estimating, Joint Hearing Before the House Committee on the Budget and the Senate Committee on the Budget, 104th Cong, 1st Sess 20-22 (GPO 1995) (written testimony of Kenneth A. Kies, Chief of Staff, Joint Committee on Taxation). In the same hearing, former CBO Director Reischauer discussed the advantages and disadvantages of including a broader range of macroeconomic effects in revenue estimates. See id at 27-31. For discussions concerning the possibility of adopting more dynamic estimating techniques, see Jane G. Gravelle, Dynamic Revenue Estimating (CRS Rep for Congress, Dec 14, 1994) (concluding that including cyclical effects, like price effects, would produce inaccurate estimates and that because of the short budget window, including permanent effects would change estimates very little); Graetz, 95 Colum $L$ Rev at 668-77 (cited in note 59).

${ }^{82}$ See Shaviro, $139 \mathrm{U} \mathrm{Pa} \mathrm{L} \mathrm{Rev} \mathrm{at} 59$ (cited in note 67) (stating that in part because of fiscal illusions, "the demand for public goods depends on how they are financed, instead of being a function merely of benefit versus cost"). See also D. Roderick Kiewiet and Mathew D. McCubbins, The Logic of Delegation 81 (Chicago 1991) (calling such procedures "heristhetic[s]" or "parliamentary stratagems that seek to change the outcomes of congressional decisions by changing perceptions about what they mean"). But see Wildavsky and Caiden, New Politics at 134 (cited in note 8) (calling the requirement of offsets "[e]nforcing the notion of opportunity costs in budgeting").

${ }^{23}$ Because I want to give only a flavor of these gimmicks, my discussion is not exhaus- 


\section{Timing gimmicks that manipulate the limited budget window.}

Budget rules require proponents of new tax breaks to offset revenue loss within a truncated budget window; PAYGO's window is five fiscal years, and that of most recent reserve funds is ten fiscal years. Moreover, despite much academic criticism, ${ }^{94}$ the cost of programs is considered on a cash flow, rather than present value, basis. ${ }^{95}$ Such a perspective means that revenue-outflows beyond the window need not be offset-neither at the time of enactment nor at the time the revenue losses occur. As a result, delaying revenue loss until the "out-years" is not an uncommon strategy for advocates of new programs. Indeed, one reason the Senate has occasionally extended the window to ten years has been to discourage such behavior, although the staff of the Joint Tax Committee warned members of Congress that "doing [ten year] estimates would have a significant adverse impact on our ability to produce timely estimates. ${ }^{996}$

tive. See, for example, OMB Mid-Session Review, Hearing of the House Budget Committee, 102d Cong, 1st Sess (July 17, 1991) (statement of Richard Darman, Director of OMB) ("While the discipline of the Budget Enforcement Act of 1990 is being adhered to, it is not ... without considerable challenge. There is probably no limit to the potential inventiveness of those who would wish to escape from the increasingly binding discipline."). For example, Laurence Kotlikoff convincingly argues that cash-flow measurements can be undermined by relabeling programs so they are accounted for differently. One can transform a transfer payment into a repayment of capital if the tax the recipient pays in early years is labeled a "loan" and the benefit, a "repayment." See Laurence J. Kotlikoff, Generational Accounting: Knowing Who Pays, and When, for What We Spend 146-61 (Free Press 1992). In many cases, a repayment is not scored as a revenue loss. Another interesting gimmick that relies on timing is the repeal of a tax on the distribution of capital that is scored as raising revenue because it reduces the lock-in effect and encourages taxpayers to realize gain earlier. Although the most well-known example is the reduction in capital gains rates (a provision discussed in text accompanying note 100), the repeal of the tax on excess distributions from qualified pension plans is a particularly interesting example of this budget trick. The repeal in Section 1073 of the 1997 tax bill is estimated to raise $\$ 62$ million over ten years; Congress had previously passed a five year moratorium on the tax, which also raised money. See Small Business Job Protection Act of 1996 \& 1452, Pub L No 104-188, 110 Stat 1755,1816 . Perhaps the only strange thing is that the 105th Congress permanently repealed the tax, rather than just extending the moratorium for another five or six years, as had been the common practice.

* See, for example, Jane G. Gravelle, Estimating Long-Run Revenue Effects of Tax Law Changes, 19 E Econ J 481 (1993). See also Daniel Shaviro, Do Deficits Matter? 104-05 (Chicago 1997) (criticizing cash-flow measurements of the federal deficit for purposes of the Balanced Budget Amendment).

*s The limited exception is discretionary credit programs, which since 1990 have been displayed in the budget on a net present value basis rather than as federal outlays occur. See Federal Credit Reform Act of 1990, Title XIII § 13201(a), Pub L No 101-508, 104 Stat 1388-1609, codified at 2 USC $\$ 661$ (1994).

* Letter from Peter v.Z. Cobb to Senator Daniel Patrick Moynihan, Chairman, Committee on Finance (Mar 23, 1994) (on file with U Chi L Rev). 
It seems likely that there is often a timing mismatch between a new tax proposal and its offset. One would not be surprised to find that many new tax expenditures tend to cost more money over time. At the same time, many offsets may not be strongly supported because they will provide less generous benefits in the future. This long-term asymmetry in the benefit streams may not be apparent within a limited budget window. More significantly for our analysis, however, interest groups can exacerbate this distortion by drafting new federal programs so that most of the revenue loss occurs in the out-years and by constructing offsets so that their proposal raises money quickly.

Timing games and accounting tricks are common throughout the federal budget arena: pay dates shift from one year to another; changes in estimated tax provisions speed up the receipt of revenue so that it falls within the budget window; and sales of capital assets provide money for new programs. For example, the recently enacted Taxpayer Relief Act of 1997 results in much higher revenue losses outside the five year PAYGO window than within it. ${ }^{97}$ Only 34 percent of the ten year net tax cut occurs in the first five years; accordingly, Congress was not required to offset two-thirds of the $\$ 292$ billion tax reduction. ${ }^{98}$ The law includes several strategically drafted provisions. A back-loaded individual retirement account ("IRA"), called the Roth IRA, loses only $\$ 1.8$ billion during the five year PAYGO window, but loses more than $\$ 20.2$ billion over ten years. ${ }^{99}$ The capital gains provision, which

${ }^{97}$ The fiscal year 1998 budget resolution contained no reserve funds for tax legislation, so Congress did not face any sanction for failing to achieve ten year revenue neutrality. The relevant enforcement provision is the PAYGO sequester that applies to the effects of legislation only through fiscal year 2002.

${ }^{\$ 3}$ See Joint Committee on Taxation, Estimated Budget Effects of the Conference Agreement on the Revenue Provisions of H.R. 2014, The "Taxpayer Relief Act of 1997," Fiscal Years 1997-2007 JCX-39-97 (July 30, 1997). See also Iris J. Lav and Robert Greenstein, The Tax Cuts in the Budget Agreement: Phase-ins, Backloading, and Revenue Acceleration Lock in Very Large Future Costs (Center on Budget and Policy Priorities 1997) (studying the original package and finding revenue losses of $\$ 650$ billion in the second ten years after enactment); Martin A. Sullivan, Tax Facts, Tax Notes 885 (Aug 18, 1997) (noting that capital gains and IRA relief more than doubles in the second five years and estate tax relief quadruples in that period); Gene Steuerle, How Fast Do Revenue Losses Accelerate?, Tax Notes 1669-70 (June 23, 1997) (detailing the profile of revenue loss for major provisions of the tax agreement and discussing feasibility of "long-term, fullyphased in" estimates). See also Martin A. Sullivan, 2002: A Budget Odyssey, Tax Notes 872-75 (Aug 18, 1997) (detailing the way that the current budget bill bunches revenue gain in 2002 so that the budget will be balanced on schedule); Ryan J. Donmoyer and Eben Halberstam, House Bill's Tax Expenditures Vary Dramatically in Long-Term Impact, Tax Notes 807 (Nov 13, 1995) (finding similar revenue loss pattern in the House tax bill proposed in the 104th Congress).

${ }^{99}$ Joint Committee on Taxation, Estimated Budget Effects. A backloaded IRA differs from current IRAs in that contributions are not deductible, but withdrawals are tax- 
is projected to raise $\$ 123$ million in the first five years as lower tax rates spur more sales, causes a revenue loss of nearly $\$ 21$ billion in the second five years. ${ }^{100}$ Other proposals are phased in over very long periods so that revenue loss is delayed until later years; for example, the original House provision to increase the exemption for the estate tax was phased in over seventeen years. ${ }^{101}$ The final bill phased in the increased exemption over nine years and delayed indexing until 1999, again skewing the revenue loss so that only 18 percent of the ten year total falls in the first five years. ${ }^{102}$

The multitude of these provisions is not surprising; moderately wily drafters can write provisions with the same present value for taxpayers (setting aside the risk of repeal I discuss below) in ways that have very different cash-flow effects. As Professor Graetz has observed:

[C]ash-flow "budget window" revenue estimates greatly influence the design of tax provisions. For example, the close relationship between investment tax credits, expensing of assets, and accelerated depreciation is well known in the tax policy literature. Reasonably sophisticated analysts, for example, can construct proposals for accelerating depreciation, partial expensing of assets' costs, or investment tax credits that are equivalent tax reductions in terms of their present value, but that involve quite different timing of the tax reductions and therefore have very different impacts on annual revenue estimates during a budget period. ${ }^{103}$

This reality might lead one to conclude that PAYGO and offset requirements that use cash-flow accounting are meaningless except to the extent that they distort and complicate tax expenditures. It might support a change to present value calculations, at least as an additional check on the process. But timing gimmicks cannot entirely eliminate the effect of PAYGO and related budget rules; practical political considerations make it difficult to con-

exempt.

${ }^{100}$ Joint Committee on Taxation, Estimated Budget Effects (cited in note 98).

${ }^{10}$ See Joan Pryde and Susan McInerney, Archer Scales Back AMT Repeal; White House Seeks Compromise in Senate, Daily Tax Rep GG-1 (June 12, 1997) (noting that Chairman Archer ultimately shortened the phase-in period to ten years, rather than seventeen). See also Sullivan, Tax Notes at 1449 (cited in note 90) ('Thirteen provisions in the [Ways and Means] chairman's mark have revenue costs in the last five years that are more than three times their cost in the first five years.").

${ }^{102}$ Joint Committee on Taxation, Estimated Budget Effects (cited in note 98).

${ }^{103}$ Graetz, 95 Colum L Rev at 673 (cited in note 59), citing Alvin C. Warren, Jr., Accelerated Capital Recovery, Debt, and Tax Arbitrage, 38 Tax Law 549, 549-50 (1985). 
struct a tax provision with delayed benefits so large that they equal (in present value terms) benefits that could be enjoyed earlier. The nature of the legislative process inherently impairs the ability of legislators to make credible promises of durability to interest groups, ${ }^{104}$ and the requirement of offsets increases the danger that one's benefits will be tempting targets to pay for new provisions. ${ }^{105}$ Strategically drafted provisions that delay the major portion of the tax expenditure's benefit are at risk of being used in early years as offsets because baseline budgeting conventions score such repeals as raising revenue, even if the provisions have never gone into effect. Groups therefore cannot be sure that a tax expenditure with delayed benefits will remain in effect long enough for them to enjoy the subsidy.

As a result of this uncertainty, interest groups may use very high discount rates when determining the present value of backloaded or phased-in benefits, and they are less likely to seek such tax programs (and less likely to reward handsomely legislators who sponsor them). For example, a Republican proposal in the 104th Congress would have allowed businesses very favorable depreciation rules in present value terms, but it would have provided most of the benefit several years after enactment. ${ }^{106}$ The business community did not enthusiastically support the proposal, in part, I think, because it was not convinced that any new provision would remain in effect long enough for businesses to enjoy. In addition, interest groups may be worried that the rather complicated language necessary to implement delayed benefits will be sufficiently opaque to include numerous traps for the unwary or provisions that undermine the drafters' promises.

2. Downstreaming decisions to the executive branch.

A less well-known way around offset requirements occurs when interest groups, sometimes with the help of Congress, influence the executive branch to implement spending programs through regulations, a process I call "downstreaming." The phenomenon of regulations substituting for legislation has long been recognized. ${ }^{107}$ Congress is not the only tax lawmaking arena in

${ }^{104}$ See text accompanying notes $165-66$. See also Garrett, 81 Cornell L Rev at $686-87$ (cited in note 7).

${ }^{105}$ See Part II.C.

${ }^{106}$ The proposal was called the Neutral Cost Recovery System. See David L. Brunbaugh and Jane G. Gravelle, The Neutral Cost Recovery System and The House Republican Contract, CRS Rep 95-161E (Jan 18, 1995) (explaining pattern of revenue loss of rules that included both an increase in the depreciation deduction and indexation).

${ }^{107}$ See Sam Peltzman, Toward a More General Theory of Regulation, 19 J L \& Econ 211 
the federal government; the Treasury Department and the Internal Revenue Service ("IRS") can affect tax benefits through their regulatory authority. ${ }^{108}$ PAYGO and similar offset requirements increase the attractiveness of action by the executive branch because the congressional rules do not apply to regulations. ${ }^{109}$ As the changes to the withholding tables showed in 1992, regulators even have the ability to provide a broad-based tax cut without offsetting the revenue loss. ${ }^{110}$

For years, Congress has succumbed to other off-budget temptations. Sometimes, these end runs are glaringly obvious. For example, as part of the 1990 budget deal, the Post Office was placed off-budget because its expected deficit would have hampered Congress's efforts to reach its goal of $\$ 500$ billion in deficit reduction. ${ }^{111}$ Lawmakers have turned increasingly to unfunded intergovernmental mandates to implement federal programs without the constraint of budget rules. ${ }^{112}$ In the same way, restrictions on

(1976); Richard A. Posner, Taxation by Regulation, 2 Bell J Econ \& Mgmt Sci 22 (1971); George J. Stigler, The Theory of Economic Regulation, 2 Bell J Econ \& Mgmt Sci 3 (1971). See also Kenneth A. Shepsle, The Congressional Budget Process: Diagnosis, Prescription, Prognosis, in W. Thomas Wander, F. Ted Herbert, and Gary W. Copeland, eds, Congressional Budgeting: Politics, Process, and Power 190, 205 (John Hopkins 1984) (discussing the substitution effects in federal budgeting and noting that there are almost always regulatory equivalents for budget policies); Hanushek, $6 \mathrm{~J}$ Pol Analysis \& Mgmt at 15 (cited in note 9) ("Regulatory activities are frequently identified . . . as being a substitute for different direct tax and expenditure activities of the government.").

${ }^{108}$ Again, my discussion here is not exhaustive because $I$ do not consider a third tax lawmaking arena, the judicial branch. Courts are not constrained by budget rules, so lawmakers have an incentive to draft broad language in the hope that the revenue estimators will not base their projections on the broadest reading. Interest groups can then use lawsuits to push the language in the direction most beneficial to them. Lawmakers may find this downstreaming alternative less satisfying because it is harder for them to claim credit for adjudicatory outcomes, and their leverage over judges is much less than the influence they wield with regulators. Once a court decision has been rendered, its effect becomes part of the baseline, and a legislative change reversing the decision can raise revenue to pay for a new tax expenditure.

${ }^{10}$ Conversely, lawmakers will prefer to legislate changes in tax provisions that will raise money rather than allowing the executive branch to promulgate regulations making the change. This trend can be problematic for several reasons. It may increase the complexity of the tax laws as such provisions are typically relatively detailed. In addition, it will decrease tax administrators' flexibility because amending the Internal Revenue Code can be more difficult than modifying regulations, particularly when the modifications lose revenue, thereby triggering offset requirements.

${ }^{110}$ President Bush announced the revision in withholding tables in his State of the Union address on January 28, 1992, 138 Cong Rec $\mathrm{H} 108$, and the new system was implemented by March 1.

${ }^{11}$ See Shuman, Politics and the Budget at 307 (cited in note 9). In the 1980s, the savings and loan bailout was placed off-budget for similar reasons. See Donald F. Kettl, Deficit Politics: Public Budgeting In Its Institutional and Historical Context 119 (Macmillan 1992).

${ }^{112}$ See Garrett, 45 U Kan L Rev at 1134 (cited in note 32). 
legislatively enacted tax expenditures result in interest groups seeking off-budget, regulatory alternatives. ${ }^{113}$ As part of their strategy, groups seek the support of members of Congress in order to pressure regulators indirectly. This tactic can work because regulators need to maintain good relations with the legislative branch that oversees their budgets and thus can intervene in their affairs. ${ }^{114}$

Often legislators are happy to oblige. If they can get some credit from interest groups for beneficial regulatory action yet still appear as deficit hawks to voters, they have lost very little by adopting budget rules. Voters see the legislative attention paid to deficit reduction and hear the rhetoric about reduced federal spending, while lawmakers quietly jawbone regulators. ${ }^{115}$ Organized groups have the resources and the motivation to monitor lawmakers and discover how they are advancing a group's regulatory agenda. Moreover, they inform their members of legislators' activities, which allows the groups to offer credible promises of electoral and financial support in return for the downstreaming.

An interesting example of the relationship among Congress, regulators, and interest groups is the treasury regulation on hedging, ${ }^{116}$ adopted as a response to the Supreme Court's decision in Arkansas Best Corp v Commissioner. ${ }^{117}$ Since the 1955 decision

${ }^{113}$ The executive branch was the target of interest group lobbying long before the current budget regime was adopted. For example, the oil and gas industry focused attention on the Tax Legislative Counsel's Office during the consideration of the 1969 Tax Reform Bill to protect the percentage depletion allowance. Oppenheimer, Oil and the Congressional Process at 86 (cited in note 80 ). Such pressure has only increased as tax legislation has become relatively costlier. See Paul Streckfus, Lobbying the IRS and Treasury: The Reg Comments You Never See, Tax Notes 881 (Feb 6, 1995) ("What may surprise some is the extent to which the IRS is now subject to taxpayer lobbying."). See also Schlozman and Tierney, Organized Interests at 272 (cited in note 67) (noting that executive branch agencies generally are the targets of lobbying by corporations and trade associations, more so than by unions and citizen groups); Wilson, Interest Groups at 59 (cited in note 65) ("The relationship between bureaucrats and interest groups in the United States is unusually suffused with politics.").

${ }^{14}$ See Schlozman and Tierney, Organized Interests at 338 (cited in note 67). The Contract with America Advancement Act of 1996 § 251, Pub L No 104-121, 110 Stat 847, 868, codified at 5 USCA $\S 801$ (Supp 1997), contains a new provision that increases Congress's leverage over the IRS and the Treasury. Regulators must now submit all final rules to the General Accounting Office ("GAO"), and Congress has sixty days to disapprove a rule by statute before it goes into effect. This legislation codifies and streamlines a power that Congress has always had: to pass a law overturning agency regulations.

${ }^{115}$ See Jonathan R. Macey, Federal Deference to Local Regulators and the Economic Theory of Regulation: Toward a Public-Choice Explanation of Federalism, 76 Va L Rev 265, 285-86 (1990); Murray Edelman, The Symbolic Uses of Politics 5, 35-36 (Illinois 1964).

${ }^{116}$ Treas Reg $\$ 1.1221-22$ (temporary regulation promulgated in Oct 1993).

${ }^{117} 485$ US 212 (1988). 
in Corn Products Refining Co $v$ Commissioner, ${ }^{118}$ taxpayers had treated as ordinary any gains or losses from hedging transactions designed to protect their trade or business from risk. The Court in Arkansas Best held that the transaction involved in the casea holding company's sale of shares in a failing bank that it had purchased as a way to add to the bank's capital and to protect its earlier investment in the bank-was the sale or disposition of capital assets, resulting in a capital loss. ${ }^{119}$ In dicta, the Court suggested more broadly that the character of gains or losses from other more traditional hedging transactions by businesses should also be capital rather than ordinary. ${ }^{120}$ The scope of Arkansas Best was therefore uncertain. The IRS took a relatively aggressive position (treating many business hedges as capital assets), ${ }^{121}$ but the few court cases on point seemed to favor treating losses from business hedges as ordinary losses. ${ }^{122}$ Numerous interest groups, including financial institutions, airlines, farmers, and even other government agencies, ${ }^{123}$ petitioned Congress to clarify the situation.

Members of the tax writing committees wanted to oblige these constituencies, but revenue concerns limited their ability to do so. Particularly before the few favorable tax court decisions, the baseline from which revenue changes were measured included assumptions based on the IRS's literal reading of the Supreme Court decision. Finding a suitable offset for a provision that estimators believed would lose billions of dollars was a serious obstacle. ${ }^{124}$ Moreover, groups resisted the idea that "fixing"

\footnotetext{
${ }^{118} 350$ US 46, 53 (1955) (holding that gains and losses from business hedging transactions are ordinary in character).

${ }^{110} 485$ US at 223.

1200 Id at 220-22.

121 See, for example, Letter from Stuart L. Brown, Associate Chief Counsel (Domestic) Office of the Chief Counsel, Department of the Treasury, Internal Revenue Service, to Henry Bahn, U.S. Department of Agriculture (Jan 27, 1993) (on file with U Chi L Rev) ("It is the litigating position of the Internal Revenue Service that short futures and options on short futures are capital assets even if they are used as business hedges by the taxpayers who acquire them.").

${ }^{12}$ See, for example, Federal National Mortgage Association v Commissioner, 100 Tax Ct No 36, Tax Ct Mem Dec (CCH) 49, 102 at 4178 (1993).

${ }^{123}$ The Department of Agriculture was concerned about the viability of its options pilot program, which was intended to convince farmers to use commodities options as an alternative to federal farm price supports. See Letter from Fifteen Members of the Senate Finance Committee to Secretary of the Treasury Lloyd Bentsen (Mar 10, 1993) (on file with U Chi L Rev).

${ }^{124}$ One tax aide who worked on the issue was told informally that the various proposals would lose billions of dollars within the budget window, and that if a provision did not require the taxpayer to identify the character when the hedges were obtained, it would cost over $\$ 10$ billion. Phone Interview with Kathleen Black, tax legislative aide to Representative Fred Grandy (Aug 30, 1994). See Lee A. Sheppard, IRS Response to Arkansas Best:
} 
their tax problem required them to find a revenue-raiser. Groups saw Arkansas Best as upending three decades of accepted business practices; they argued that their proposals merely restored the status quo ante.

For several years, members sent letters and met with Treasury officials in both the Bush and Clinton Administrations, seeking a regulatory solution but to no avail. ${ }^{125}$ Treasury officials were sympathetic, reflecting the consensus of the tax policy community that the Court's broad dicta on the character issue was wrong. ${ }^{126}$ Nonetheless, executive branch officials worried both that a regulatory solution would exceed Treasury's delegated authority and that adopting regulations that lost such significant revenue would set an unfortunate precedent. (The latter concern was assuaged when the Service began to lose cases litigated in the wake of Arkansas Best.) Finally, in the conference report for HR 2264, the 1993 Omnibus Budget Reconciliation Act, the conferees included the following directive:

The conferees understand that hedging transactions are ... important to the management of risks by businesses . . . [and] are part of a sound business strategy in fields as diverse as farming, banking, manufacturing, and energy production. However, the conferees understand that there may be a level of uncertainty regarding the tax treatment of such hedging transactions .... The conferees believe that this is a significant issue. To the extent a solution to this issue may require coordination between the executive and legislative branches, the conferees urge the Administration, in the strongest terms, to advise the House Ways and Means and the Senate Finance Committees, within 90 days of the enactment of this Act, how best to proceed. ${ }^{127}$

What the Reporter Saw, Tax Notes 548, 549 (Aug 3, 1992) ("[T]he uncertain state of the law applicable to hedging caused a revenue-scoring problem. If a literal reading of Arkansas Best was the baseline, change would be costly. Facing a no-win situation, tax policymakers threw up their hands.").

${ }^{125}$ See Letter from Fifteen Members of the Senate Finance Committee to Fred T. Goldberg, Jr., Assistant Secretary (Tax Policy), Department of the Treasury (July 8, 1992) (on file with U Chi L Rev); Letter to Secretary Lloyd Bentsen (cited in note 123).

${ }^{125}$ See, for example, Myron C. Grauer, A Case for Congressional Facilitation of a Collaborative Model of Statutory Interpretation in the Tax Area: Lessons to be Learned from the Corn Products and Arkansas Best Cases and the Historical Development of the Statutory Definition of “Capital Asset(s)", 84 Ky L J 1, 24-25, 56 (1995-96); Edward D. Kleinbard and Suzanne F. Greenberg, Business Hedges After Arkansas Best, 43 Tax L Rev 393, 414, 419 (1988).

${ }^{127} 139$ Cong Rec H 5950 (Aug 4, 1993) (explanation of Section 13223 of the conference agreement, new Section 475 of the Internal Revenue Code). 
This language, buried in pages of dense and technical descriptions of tax legislation, is code. The tax writing committees did not want to "coordinate" a response-coordination might require legislation. They wanted, "in the strongest terms," for the executive branch to adopt regulations that would fix the Arkansas Best problem and assuage the demands of the many powerful interest groups - a fix that for budget purposes was free. The conference report's unambiguous signal reduced the executive branch's concern that its action would exceed its legal authority. Within three months, the Treasury issued a new hedging regulation, allowing ordinary treatment of business hedges designed to reduce the risk of price changes, currency fluctuations, or interest rate changes as long as the hedges are identified when acquired. ${ }^{123}$ It seemed that most of the problems caused by Arkansas Best had been solved, and in a way that allowed Congress to claim credit without triggering offset requirements.

Recent developments concerning the hedging regulation demonstrate an additional "bootstrapping benefit" for groups that succeed in downstreaming. The hedging regulation has now been attacked as invalid, primarily because it purports to be exclusive and to supplant conflicting case law. ${ }^{129}$ Again, uncertainty has prompted calls for legislation. ${ }^{130}$ But the projected revenue loss is negligible now because the budget baseline includes the current regulation. ${ }^{131}$ Merely codifying a current regulation affects revenues only slightly, if at all, because codification of existing practice is not expected to change taxpayer behavior significantly. In other words, a downstreaming strategy pays off for interest groups even if the regulation that is issued may be invalid. As long as Congress can codify the regulation before it is overturned, the post-downstreaming legislation requires only a minimal offset, unlike legislation that would have solved the problem in the first instance.

The Arkansas Best situation is somewhat unusual. Congress does not usually intervene via instructions in a committee report, ${ }^{132}$ and a downstreaming proposal does not often prompt the

${ }^{123}$ Treas Reg § 1.1221-22.

${ }^{120}$ See Farmland Industries $v$ Commissioner, Tax Ct No 11881-93. See also Lee A. Sheppard, Hedging vs. Risk Management, Tax Notes 1300, 1303-04 (June 9, 1997).

${ }^{20}$ See Department of the Treasury, Taxpayer Bill of Rights 3 and Tax Simplification Proposals (Apr 16, 1997). See also Heidi Glenn and Sheryl Stratton, Treasury's Simplification Plan Includes Taxpayer Bill of Rights 3, Tax Notes 305 (Apr 21, 1997).

${ }^{\text {t3 }}$ See Sheppard, Tax Notes at 1303. Of course, revenue estimators do consider the revenue loss associated with regulations that they expect the executive branch will issue to implement new tax provisions.

${ }^{132}$ See 26 USCA $\S 513$ (Supp 1997) (exempting sponsorship payments from unrelated 
support of tax policy commentators in addition to the organized groups pursuing their economic self-interest. Other examples of downstreaming, such as the exception for state-sponsored prepaid tuition programs provided in the contingent payment debt instrument regulations, lacked convincing policy justifications and should be seen primarily as a result of interest group clout. ${ }^{133}$ As offset requirements continue to reduce the ability of groups to get tax benefits from Congress, advocates of tax expenditures will turn increasingly to off-budget sources such as regulations. Again, however, this tactic does not negate entirely the discipline of PAYGO: regulators often resist the entreaties of interest groups and lawmakers, as supporters of capital gains tax relief discovered when the Bush Administration seriously considered reducing such taxes through regulation but decided against it for lack of authority. ${ }^{134}$

\section{Offset Requirements Impose Post-Enactment Costs on Recipients of Tax Benefits}

Regardless of which method is used to secure a tax benefit, once it is obtained, the group must shift gears and begin protecting it from predators. The costs of this defense are the "post-

business taxable income with negligible revenue effect); Fred Stokeld, Lobbyists, Ex-Hill Staffers Deny Undue Influence on EO Division, Tax Notes 1396 (Sept 18, 1995) (detailing congressional involvement in regulations governing the tax treatment for tax-exempt organizations of corporate sponsorship payments); Nathan Wirtschafter, Note, Fourth Quarter Choke: How the IRS Blew the Corporate Sponsorship Game, 27 Loyola LA L Rev 1465 (1994) (same); Phone Interview with Candi Perotti Wolff, then tax aide to Senator Malcolm Wallop (Aug 30, 1994) (noting that revenue constraints prohibited Congress from solving problems with implementing the diesel dyeing requirements and indicating that congressional jawboning had influenced the regulations); David S. Hilzenrath, The Hues and Cries Over Diesel Dyes, Wash Post F1 (Nov 3, 1993) (discussing regulatory difficulties with implementing diesel fuel dyeing requirements).

${ }^{123}$ The prepaid tuition program exception is also an example of costless codification after successful downstreaming. Members of Congress pressured the executive branch to exempt state-sponsored plans from taxation and overcame Treasury's recalcitrance in part by threatening to make it a campaign issue in the 1996 presidential race. One day after the Treasury "clarified its position" that the plans would not be included in the regulations, the Senate Finance Committee added a provision codifying the exception. Because the baseline included the Treasury's decision, the legislation was scored as losing no revenue, and it was enacted as part of the final bill. Before the regulatory action, estimators indicated that the legislative proposal would lose several hundred million dollars within the PAYGO window. See Small Business Job Protection Act of 1996 § 1806, Pub L No 104 188, 110 Stat 1755, 1865, codified at 26 USCA § 529 (Supp 1997); Sheryl Stratton, Prepaid Thition Programs Major in Political Science, Tax Notes Today Doc 96-19141 (July 3, 1996).

${ }^{134}$ See President Bush's Statement on Indexing Capital Gains, White House News Release, in Tax Notes Today Doc 92-8297 (Sept 8, 1992) (expressing disappointment at Justice's determination that the executive branch could not unilaterally index capital gains). 
enactment costs" of PAYGO and similar congressional rules. Because any tax expenditure-whether in traditional legislation, laws with delayed implementation, or off-budget regulationscan represent revenue to those seeking a new federal tax program, the beneficiaries must expend resources guarding their tax subsidy from others in search of an offset. Although delayed provisions do not lose revenue currently, future revenue loss is included in the baseline. Estimators will therefore consider that a repeal will raise money in the years when the provision would have been effective. Similarly, baselines reflect the revenue effects of regulations, so legislative modifications to them also can raise revenue. Granted, tax provisions always have been at some risk of being repealed or scaled back, thus forcing beneficiaries to work to avoid losing valuable expenditures. ${ }^{135}$ However, offset requirements increase this risk because every new tax subsidy must be paid for by a change in existing tax or entitlement laws.

The increased uncertainty about the durability of tax provisions has several important effects that I will discuss later; ${ }^{136}$ for example, it affects the relationship between lawmakers and interest groups, and it may result in increased scrutiny of existing tax provisions. At this point, however, my focus is on the costs involved in protecting a tax benefit and the strategies employed in such an endeavor. Again, an interest group must consider these post-enactment costs, as well as the up-front costs, when deciding whether the benefits of a tax expenditure justify the effort to enact it. Although the future costs will be discounted, they add to the burden imposed on those currently seeking new federal programs. This added burden should reduce the number of new expenditures enacted, relative to the number that would be enacted in a budget process without offset requirements. In addition, beneficiaries of tax provisions enacted before PAYGO must also embark on strategies of protection to ensure that they continue to profit from federal subsidies through the Internal Revenue Code.

Groups have a variety of protective mechanisms available to them; these strategies include both monitoring and signaling activities. First, monitoring costs are incurred as interest groups and their lobbyists invest resources to discover possible threats. ${ }^{137}$

\footnotetext{
${ }^{135}$ See Fred S. McChesney, Money for Nothing: Politicians, Rent Extraction, and Political Extortion 23 (Harvard 1997) (Groups continue to pressure legislators to protect themselves against "windfall losses" that could occur if benefits were repealed or reduced.).

${ }^{136}$ See Parts II.D and III.

${ }^{25}$ See, for example, Robert H. Salisbury, Putting Interests Back into Interest Groups, in Cigler and Loomis, eds, Interest Group Politics 371, 382 (cited in note 74) (noting that "a significant amount of time and energy [of interest groups] is devoted to monitoring,
} 
They read and analyze the same sources used by groups who are trying to identify offsets. ${ }^{138}$ They watch for new revenue estimates, which might increase the attractiveness of their benefit, or for new players, such as the administration or key congressional leaders, who might label their expenditure as an unproductive "tax loophole" or an example of insidious "corporate welfare." They pay particularly close attention during committee mark-ups that may go late into the evening (or into the early morning), because these may result in the unveiling of carefully guarded offset proposals-sometimes to the surprise of the unwitting targets. ${ }^{139}$ Defeating an offset proposal is more difficult once it appears in a bill that has passed the committee; it can usually occur only in conference because successful floor amendments are unlikely. ${ }^{140}$

Second, and perhaps more prevalent in the budget process than in other legislative contexts, is signaling, ${ }^{141}$ a strategy that current beneficiaries of tax expenditures use to indicate to lawmakers and other interest groups that particular offset proposals will generate substantial opposition. Remember that groups seeking to enact a new provision hope to find an offset that is not aggressively defended. This strategy will reduce up-front costs, although it will not eliminate the costs that arise from competition with other predators. A credible signal of vigorous opposition by those protecting the possible target may be enough to remove

tracking, and assessing the activities of governmental officials"); id at 377 ("It follows from what has been said that interest groups will spend a great deal of their time and effort watching what the government does and monitoring policy developments to see how their group interests might be affected.").

${ }^{233}$ See text accompanying notes 58-63. See also Bradley, Lobbying Fever (cited in note 83) (quoting chief lobbyist for the National Association of Realtors about an offset proposal that would affect the real estate industry: "We knew that in all probability this issue would be on the table and we would have a real fight on our hands. So that's when we really cranked up the effort and put on the full court press.").

${ }^{129}$ See, for example, Matlack, Natl $\mathrm{J}$ at 267 (cited in note 56) (discussing lobbyist for Iron-Ore Co of Canada (now the Chief of Staff of the Joint Tax Committee) who paid for an exemption from the corporate minimum tax with a last minute proposal to tighten the rules on the tax deductibility of mobile phones used for business). See also Handler, Tax Notes at 1268 (cited in note 60) ("The current budget reconciliation system, since it puts a substantial premium on advance knowledge of the direction of legislative proposals, has made special interest groups more powerful than ever.").

${ }^{140}$ See text accompanying notes $45-47$ and 82 .

${ }^{141}$ See, for example, Gretchen Morgenson, Look Who's Running a Protection Racket, Forbes 44 (Sept 8, 1997) (quoting chief lobbyist for the National Federation of Retailers: "What's true in the jungle is true in Washington: If you appear to be weak, you become prey."). A related concept of signaling has been developed in the literature that analyzes congressional oversight of administrative agencies. See, for example, David Epstein and Sharyn O'Halloran, A Theory of Strategic Oversight: Congress, Lobbyists, and the Bureaucracy, $11 \mathrm{~J} \mathrm{~L}$ Econ \& Org 227 (1995); Mathew D. McCubbins and Thomas Schwartz, Congressional Oversight Overlooked: Police Patrols versus Fire Alarms, 28 Am J Pol Sci 165 (1984). 
the provision from consideration. There are a number of signals that can be used, either individually or in combination; these signals can be costly enough to impart credible information and to provide a secure defense. ${ }^{142}$ To give a flavor of such strategies, I will focus briefly on two: building coalitions and establishing connections to key congressional players. ${ }^{143}$

Increasingly, modern interest group activity involves forming coalitions of groups with similar interests with regard to a particular issue or set of issues. ${ }^{144}$ Coalitions are formed (or maintained) both to seek new tax expenditures and to protect existing benefits. Perhaps most importantly, coalitions can expand the base of apparent support along many dimensions. For example, the coalition supporting the targeted jobs tax credit $^{145}$ included not only the employers and representatives of disadvantaged groups, but also the management assistance companies, who were organized and well-funded. The size and composition of a coalition can provide valuable information for predators, especially when revenue estimates do not reveal the extent to which groups benefit from the dynamic effects of tax provisions. Coordination among groups also can reveal that their supporters span numerous congressional districts and that they have connections to more members of Congress than one group alone might command. In addition, coalitions are often nonpartisan, so they have the advantage of bipartisan support. Groups rich in financial resources can work beside other groups equipped with hundreds of supporters; together, they can devise a well-funded and effective grassroots strategy. Many of these coalitions are formed in anticipation of an attack (often by Washington lobbyists who spe-

${ }^{142}$ Just as we saw before, smaller groups that can organize more easily and have substantial resources are more effective at deploying these strategies (this time, to protect the status quo, rather than to obtain a new benefit) than are groups representing large segments of the public. See McCubbins and Schwartz, $28 \mathrm{Am}$ J Pol Sci at 172 (cited in note 141).

${ }^{143}$ Professors Stein and Bickers describe similar strategies in a related budget context, terming them maintenance strategies. Robert M. Stein and Kenneth N. Bickers, Perpetuating the Pork Barrel: Policy Subsystems and American Democracy 96 (Cambridge 1995).

${ }^{14}$ See Diana M. Evans, Lobbying the Committee: Interest Groups and the House Public Works and Transportation Committee, in Cigler and Loomis, eds, Interest Group Politics 257, 262 (cited in note 74) ("One study of Washington lobbyists showed that 90 percent of the organizations surveyed participated in coalitions and found themselves doing so increasingly since the 1970 s."); Burdett A. Loomis, Coalitions of Interest: Building Bridges in the Balkanized State, in Allan J. Cigler and Burdett A. Loomis, eds, Interest Group Politics 258, 259 (CQ 2d ed 1986) (detailing long history of coalitions in American politics); Terry M. Moe, The Organization of Interests: Incentives and the Internal Dynamics of Political Interest Groups 62-63 (Chicago 1980) (discussing process of forming coalitions and various kinds of coalitions that are formed).

${ }^{145}$ See text accompanying notes 75-76. 
cialize in brokering coalitions ${ }^{146}$ ). They swing into action only when monitoring suggests a need, for example, when their provision appears in a list of disfavored corporate welfare subsidies or when it is listed as an option for deficit reduction by a think tank or expert congressional staff.

One of the strongest coalitions in the tax arena has been the AMT Working Group. ${ }^{147}$ The Group is a coalition of diverse, capital-intensive businesses that was formed both to defeat proposals that would raise the corporate alternative minimum tax ("AMT") and to soften the provisions enacted as part of the 1986 Tax Reform Act. The National Association of Manufacturers, a trade organization that is itself a coalition of related businesses, initially provided much of the coordination for the Group. Although the Group has supported a variety of proposals to reach its goals, ${ }^{148}$ one initial effort was to convince members of Congress that increasing the AMT would be disastrous for important constituents. In other words, the apparently vigorous offense was designed in part to provide a strong defense against any expansion of the AMT. ${ }^{149}$ Recently, the Group's efforts successfully convinced lawmakers to pass nearly $\$ 20$ billion in AMT relief. ${ }^{150}$

Of course, coalitions are not invincible. Moreover, the larger and broader the coalition, the more susceptible it may be to tactics that divide members and dissipate its strength. Those forming coalitions thus face a difficult tension. On the one hand, as Professor Lowi succinctly states, "Large coalitions beat small coalitions. ${ }^{p 151}$ On the other hand, large coalitions often comprise groups whose interests are aligned but not identical. Accordingly, a funding predator can modify the offset to satisfy the concerns of some of the coalition members, thereby reducing the level of the opposition and perhaps the coalition's ability to succeed in its protection strategy. A predator can carve out exceptions, include grandfather provisions or other transition relief, or redraft the offset proposal to affect important members only incidentally.

${ }^{146}$ See Loomis, Coalitions of Interest at 270-72 (cited in note 144).

${ }^{14}$ See Companies in the "AMT Working Group" (Lobbying for Alternative Minimum Tax Cuts), Tax Notes Today Doc 95-8757 (May 4, 1995).

${ }^{14}$ See, for example, Minimum Tax Reform Act of 1993, S 858, 103d Cong, 1st Sess (Apr 19, 1993), in 139 Cong Rec S 5280 (Apr 30, 1993).

${ }^{149}$ See, for example, 138 Cong Rec S 3628-30 (Mar 13, 1992) (opposing amendment to increase the corporate AMT rate to pay for a child care tax credit).

${ }^{150}$ See, for example, Taxpayer Relief Act of $1997 \S 401$, Pub L No 105-34, 111 Stat 789, 843 , codified at 26 USCA § 55 (Supp 1997) (providing AMT exemption for small businesses and more generous depreciation allowances).

${ }^{151}$ Theodore J. Lowi, American Business, Public Policy, Case-Studies, and Political Theory, 16 World Politics 677, 678 (1964). 
Certainly, these modifications reduce the amount of revenue raised by the offset and limit the size of the new tax benefit, but a small tax expenditure in some cases will be better than none. And if members of the target coalition believe a predator is likely to prevail, they may be willing to negotiate such deals in order to retain some salvage value from the tax expenditure, rather than walk away empty-handed.

The proposed BTU tax on energy that was part of President Clinton's first budget submission ${ }^{162}$ provides a good example of both the internal dynamics of coalitions and the difficulty of maintaining a solid front when members' interests diverge. Again the National Association of Manufacturers, an expert coalition broker, formed a coalition to oppose the tax: the Affordable Energy Alliance, which included over nine hundred businesses and groups. ${ }^{153}$ The possibility of rifts between members was apparent when the coalition was formed and some natural allies declined to join. One crucial player, the Independent Petroleum Association of America ("IPAA"), did not participate. Instead, the IPAA wanted to preserve its flexibility and be able to cut its own deal (in this case, to move the collection point of any tax away from the wellhead and perhaps to enact a new tax expenditure for independent producers). ${ }^{154}$ Ultimately, supporters of an energy tax managed to craft a compromise that gained the support of some members of the coalition. This compromise led Congress to replace the BTU tax with a smaller transportation fuels tax, which was not strongly opposed by energy intensive manufacturing companies, utility companies, and the major energy producers. It did, however, place significant burdens on trucking companies, railroads, and businesses that rely substantially on transportation services. ${ }^{165}$ Even at this point, the remaining opponents tried to strike side deals in return for support. The American Association of Railroads indicated a willingness to support the new tax in return for the future elimination of another tax on railroad fuel, a

${ }^{152}$ Office of Management and Budget, $A$ Vision of Change for America 105 (GPO 1993).

${ }^{153}$ Energy-Intensive Businesses Form Coalition to Fight BTU Tax, NAM Announces, Daily Tax Rep G-7 (May 6, 1993).

is See Timothy Noah, BTU Tax is Dying Death of a Thousand Cuts As Lobbyists Seem Able to Write Own Exemptions, Wall St J A18 (June 8, 1993).

${ }^{155}$ See The More than 900 Members of the Affordable Energy Alliance (as of May 5, 1993) (on file with $U$ Chi $L$ Rev). A more recent example of a coalition that experienced cleavages was that of the airlines that opposed airline tax increases. Domestic and international carriers had different interests, as did regional and national carriers. See Jeremy Holmes, Aviation Tax Increases Will Face Tough Battles Before Final Bill is Drafted, Daily Tax Rep G-6, G-7 (June 26, 1997). Ultimately, Congress adopted a per-segment tax that will burden the small regional companies more than the national airlines. 
deal similar to one already obtained by the truckers. ${ }^{156}$ As this example illustrates, the leaders of coalitions must spend time not only lobbying members of Congress but also ensuring that the coalition remains cohesive and that members do not enter into individual bargains that undermine the general goals of the coalition.

Whether part of a coalition or not, current beneficiaries of tax expenditures also spend time forming and maintaining connections with members of Congress and other participants in federal lawmaking. In this process, the fact that groups are seeking to block legislation rather than pass it is a tremendous advantage. Because legislation can be stopped at many points along the legislative path, groups need only to secure the assistance of one key player to succeed. Many groups possess ties to important lawmakers that were established during their quest to enact a tax subsidy. Furthermore, because budget procedures and other congressional rules reduce the ability of lawmakers to amend bills on the floor, groups can receive the maximum return on their scarce resources by concentrating on the Finance and Ways and Means Committees. The electoral strength of incumbents, combined with a strong seniority system that largely determines committee assignments, gives organized groups great certainty about which legislator will occupy a strategic position in the system. ${ }^{157}$

To block attacks at any stage in the legislative process, groups must communicate publicly the strong support of the pivotal lawmakers. There are myriad ways to accomplish such signaling. For example, sympathetic lawmakers can force votes on nonbinding Sense of the Senate provisions, ${ }^{168}$ creating a public record of support for various positions. This signal, however, lacks some credibility because of its relatively low cost. ${ }^{159}$ Committee members use hearings and mark-ups to signal their support for particular tax provisions or their allegiance to certain constituencies. ${ }^{160}$ An example of a strong defense signal occurred during the

${ }^{158}$ See Memorandum from J.D. Williams to Senator Boren, Railroad Industry Support of Energy Tax (June 11, 1993) (on file with U Chi L Rev).

${ }^{157}$ See Garrett, 81 Cornell L Rev at 687 (cited in note 7).

${ }^{158} \mathrm{~A}$ "Sense of the Senate" provision is nonbinding legislation that expresses the sense of the Senate on an issue. While the vote is binding, the provision is aspirational.

${ }^{159}$ See, for example, $H$ Con Res 64, Concurrent Resolution Setting Forth the Congressional Budget for the United States Government for the Fiscal Years 1994, 1995, 1996, 1997 and 1998, $H$ Rep No 103-48 \& 13, 103d Cong, 1st Sess (Mar 3, 1993) (setting forth a variety of Sense of the Senate provisions, many dealing with the proposed BTU tax on energy).

${ }^{100}$ See, for example, Administration's Energy Tax Proposals, Hearings Before the Senate Committee on Finance, S Hrg 103-215, 103d Cong, 1st Sess 17-18 (GPO 1993) (statement of Senator Conrad concerning the effect of the energy tax on agriculture); id at 25-26 
consideration of the recent tax bill. Even as the Ways and Means Committee finished filling out the details of the newly passed tax programs, the leaders of both houses publicized a letter that they had sent to President Clinton specifying that the low-income housing tax credit should not be used as a revenue-raiser. This letter was a rapid response to suggestions that the White House and Chairman Archer were considering eliminating the politically popular tax expenditure as a way to pay for new tax programs. ${ }^{161}$ Such a public commitment by the congressional leadership presents a formidable barrier to funding predators in the budget context, which is influenced heavily by party leaders, as well as by committee members.

In sum, offset requirements seem well-designed to achieve their objective: to make it more difficult to enact new federal programs through the tax code. They increase the costs of obtaining a new tax expenditure, and they also increase the costs of maintaining it once it is obtained. Groups know that any benefit they manage to enact is susceptible to repeal or modification. Thus, the costs will continue to mount as groups work to discover any threats and to discourage raids by projecting a strong and visible opposition. If these conclusions are right, PAYGO and related provisions have worked a significant change in federal budgeting by intensifying and institutionalizing conflict among interest groups. This leaves us with a puzzle to resolve before turning to the other ramifications of these budget rules, namely, why would self-interested legislators, eager to please constituents and interest groups, adopt these requirements and thereby transform the tax legislative arena?

\section{Legislators' Motivations for Adopting Offset Requirements}

Scholars who wish to present the legislative process accurately must give careful attention to all the relevant parties. Interest groups and voters are crucial determinants of public policy, but so are the legislators themselves. They are more than conduits in the process of turning constituents' desires into law; ${ }^{162}$

(statement of Senator Boren concerning the effect of the tax on independent producers).

${ }^{161}$ See Joan Pryde, Lott Says Low-Income Housing Credit Will be Protected Under Budget Pact, Daily Tax Rep G-5 (May 15, 1997).

${ }^{162}$ See Hamilton, 69 NYU L Rev at 499 (cited in note 69) (contesting traditional public choice view of legislator as "toll gate" for interest groups); McChesney, Money for Nothing at 17 (cited in note 135) (criticizing the economic theory of regulation for failing to recognize that legislators are more than mere brokers who "do not actively enter the market for rents with their own demands"); Schlozman and Tierney, Organized Interests at 396-97 (cited in note 67) (noting that lawmakers are more than "mere referee[s]" mediating the various demands of interest groups). See also Garrett, 81 Cornell L Rev at 660-62 (cited in 
they also seek to achieve certain personal goals from holding office and will act to further their own interests when deciding how to legislate. A politician cannot satisfy her preferences unless she remains in office, so she is inevitably interested in receiving the financial and electoral support necessary to assure reelection. Thus, for the most part, one would assume that her interests are aligned with groups that can provide such aid and that she would favor congressional rules and procedures that facilitate her ability to establish federal programs and dispense benefits to supporters and constituents.

Offset requirements are not consistent with this legislative strategy. As I have detailed, they increase the cost of enacting valuable tax expenditures. Not only does this situation distress many hopeful interest groups and their would-be benefactors, but it also reduces the ability of lawmakers to exercise influence and power and impedes politicians whose policy goals can be achieved only through increased federal spending. ${ }^{163}$ Moreover, as I have discussed, ${ }^{164}$ PAYGO and similar provisions threaten to erode the durability (and thus the present value) of both existing benefits and any tax expenditures that are enacted. In short, budget rules both make it harder to obtain a product and render that product less valuable. This dual consequence should decrease the willingness of groups to enter the legislative market and reduce the fundraising ability of members of Congress-not a desirable outcome for members of Congress.

Before we try to solve this puzzle, it is worth focusing on the importance of durable commitments in the legislative process. Legislative deals are inherently unstable, as new lawmakers, who were not parties to original arrangements, enter the legislature or as current lawmakers act opportunistically to curry favor from new interests. ${ }^{165}$ However, because lawmakers can receive

note 7) (discussing the goals that motivate politicians and the importance of the threshold objective of reelection to satisfying all others; also surveying relevant literature).

${ }^{16}$ In some cases, the political ideology of lawmakers may cause them to favor greater hurdles to legislation, for example, lawmakers who favor reduced federal influence generally or a smaller federal government. Depending on the nature of congressional rules, however, new procedures may frustrate even these legislators if part of their political agenda involves dismantling current federal programs. But offset requirements should not stand in their way because the impediments they establish are not triggered by efforts to repeal existing tax expenditures or to eliminate direct spending-moves that raise, rather than lose, revenue.

${ }^{14}$ See text accompanying notes 104-06.

${ }^{16}$ See McChesney, Money for Nothing at 23 (cited in note 135) ("A legislator not party to the original bargain has less incentive to abide by the political rent-creation deal struck by his predecessors unless he too is compensated. Guaranteed rent durability is thus impossible."); id at 89 ("Opportunism is possible because the contracts to which politicians 
more financial and electoral support from each beneficiary group if they offer more durable deals, a variety of institutions have developed to entrench bargains. For example, incumbency reinforced with a strong seniority system and a stable committee structure assures interest groups that the lawmakers with whom they bargain will remain in office for years, even decades, and will occupy positions where they can ward off attempts to repeal existing tax benefits. ${ }^{166}$

Nonetheless, durability is still a scarce legislative commodity, particularly in the tax arena. Even before the formalization of offset requirements, the rate of change to the tax laws was increasing, undermining certainty and durability. ${ }^{167}$ In part, budget considerations drove this acceleration because Congress often attempted to meet increasingly elusive deficit targets through reconciliation bills with large revenue components. This situation led Professor McChesney to conclude that, "Congress routinely contracts over taxation, but only for a certain period. Benefits can

agree are executory. In return for consideration conferred now by taxpayers, the politician will be expected to perform his part of the deal later, forbearing in the future from tax or other legislation not in the interests of the private contributor.").

${ }^{165}$ See Garrett, 81 Cornell L Rev at 687 (cited in note 7). See also W. Mark Crain and Timothy Muris, Legislative Organization of Fiscal Policy, 38 J L \& Econ 311, 320 (1995) (discussing advantages for durability of stability among committee chairmen); W. Mark Crain, Legislatures and the Durability of Deficits, in James M. Buchanan, Charles $\mathrm{K}$. Rowley, and Robert D. Tollison, eds, Deficits 281, 282 (Basil Blackwell 1986) (discussing how committees function as "a means to cement current political agreements"). See generally W. Mark Crain and Robert D. Tollison, Time Inconsistency and Fiscal Policy: Empirical Analysis of US States, 1969-89, 51 J Pub Econ 153, 166 (1993) (noting that placing restrictions on the ability of a future legislature to renege on current deals gives legislative contracts a higher present value and detailing possible restrictions that Congress could adopt); William N. Landes and Richard A. Posner, The Independent Judiciary in an Interest-Group Perspective, $18 \mathrm{~J}$ L \& Econ 875, 878 (1975) ("The element of stability or continuity necessary to enable interest-group politics to operate in the legislative arena is supplied, in the first instance, by the procedural rules of the legislature, and in the second instance by the existence of an independent judiciary.").

${ }^{107}$ Indeed, Eugene Steuerle labeled the 1980s "The Tax Decade" because of the salience and frequency of tax legislation during this period. G. Eugene Steuerle, The Tax Decade (cited in note 4). See also Richard L. Doernberg and Fred S. McChesney, On the Accelerating Rate and Decreasing Durability of Tax Reform, 71 Minn L Rev 913, 920-23 (1987) (reviewing studies of accelerating pace of legislative change in the tax law); Harold I. Apolinsky, This is Tax Reform? The Changes Just Cost Money, Wash Post C8 (Apr 6, 1986) (finding that while in the past, major tax reform occurred approximately once every fifteen years, from 1976-84, six major tax bills had been passed making over 5,800 changes in the tax code); Witte, Politics and Development of Income Tax at 290 (cited in note 66) (noting increase in the pace of enacting and modifying tax expenditures). But see David J. Shakow, The Flood of Tax Legislation, Tax Notes 521, 522 (Apr 22, 1996) (putting the change in tax legislation into a larger perspective and concluding that "compared to all new legislation, the trend of tax laws since 1954 has been generally to decrease over time, and the increase that did occur in the middle $1980 \mathrm{~s}$ was much less dramatic than a simple page count would suggest”). 
be rented briefly, not purchased for all time. Moreover, one also discovers, the rental period available on tax relief is of decreasing durability. ${ }^{\prime 168}$ One might have expected Congress to construct institutions that could reverse this trend. Instead, they institutionalized PAYGO and further destabilized tax lawmaking.

One possible reason behind this surprising behavior is that lawmakers adopted offset requirements without fully understanding the extent to which they would change the dynamics of tax legislation, instead believing that the new rules were largely empty symbolic gestures. The conditions surrounding budgeting are particularly ripe for symbolic lawmaking; unlike the special interests to whom legislators direct substantive lawmaking, those concerned with the deficit tend to be unorganized, ill-informed groups. ${ }^{169}$ Reassuring the public with purely symbolic budget rules, legislators could continue to send tangible resources to the organized groups, who have superior information and clout. Moreover, because their concerns about the federal budget are more abstract than specific, the general public might be easily contented with symbolism. Polls and other data consistently reveal that while voters proclaim they are deficit hawks and desire smaller government, they also support numerous, expensive federal programs and are unwilling to make the kinds of spending sacrifices necessary to meet their professed deficit goals. For example, while they identify the budget deficit as the most important issue facing the federal government, ${ }^{170}$ most Americans also want to maintain Medicare spending at its current level, even if that undermines deficit reduction. ${ }^{171}$ More than half would prefer a budget that makes smaller cuts in programs, even at the price of a higher deficit, than a budget containing more deficit reduction but deeper cuts in programs. ${ }^{172}$ In other words, the electorate

${ }^{168}$ McChesney, Money for Nothing at 95 (cited in note 135).

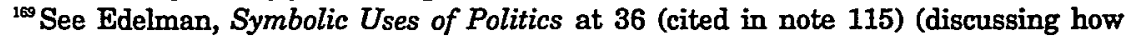
legislators use symbolism to satisfy large, unorganized, and ill-informed groups, which he calls Pattern B groups, while sending real benefits to the organized, which he calls Pattern A groups); Hayes, Lobbyists and Legislators at 69 (cited in note 77); Loomis and Cigler, Introduction at 5 (cited in note 74). See also Shaviro, $139 \mathrm{U} \mathrm{Pa} \mathrm{L} \mathrm{Rev} \mathrm{at} \mathrm{47-48} \mathrm{(cited}$ in note 67) (applying Edelman's theory to tax reform legislation). How issues become salient to members of Pattern B groups is a complex question. In this Article, I do not attempt to trace how the federal deficit became a matter of such public concern that it prompted Congress to adopt GRH and other budget rules. For a discussion of this, see generally Shaviro, Do Deficits Matter? (cited in note 94).

${ }^{170}$ Harris Poll (June 5, 1997) (reporting that 19 percent identifying it as one of the two most important issues).

${ }^{171}$ NBC News/Wall St J Poll (Oct 31, 1995) (reporting that 52 percent wanted Medicare spending maintained even at the cost of deficit reduction).

${ }^{172}$ NBC News/Wall St J Poll (Aug 1, 1995) (reporting that 55 percent favored the former). See also 139 Cong Rec S 10706 (daily ed, Aug 6, 1993) (statement of Senator Robert 
might not only be mollified by symbols, they might actually reject incumbents who delivered more than symbolic action on the deficit.

The problem with this explanation is that the rules are more than empty gestures. Requirements of revenue neutrality increase the costs of enacting tax expenditures and undermine their durability. Perhaps everyone simply adopted real change by mistake. That supposition seems rather unpersuasive, however, because PAYGO was codified after years of experience both with the informal norm of revenue neutrality and with GRH's offset requirements for discretionary spending. Perhaps the demand for some action with regard to deficit spending was so pressing that, in order to stave off this short-term electoral threat, legislators were forced to adopt offset requirements, hoping they would have only minimal effects on their long-term ability to extract rents and enact new programs. ${ }^{173}$

A different group of observers of the legislative process might offer a second explanation for the adoption of these budget rules. Rather than leaving underlying relationships between organized interests and lawmakers untouched, they might argue, offset requirements clearly alter the balance-but to the advantage of the lawmakers themselves (or, at least, not to their disadvantage). In short, PAYGO is entirely consistent with the notion that legislators act in their own self-interest, because they will continue to receive as much, if not more, financial rewards from organized interests while appearing to the voters to be making real headway on the federal deficit. This argument still relies on the notion of symbolism in that lawmakers are not particularly concerned that budget rules actually decrease the deficit (although such a result might make their campaign claims more credible). But this explanation differs from the previous one because organized, wellinformed interest groups may be unable to receive the same amount of benefits as they did before PAYGO. Here, I am extrapolating in part from the work of Professor McChesney and his theory of rent extraction. ${ }^{174}$

Kerrey) (arguing that budget problems "exist because of rapid, uncontrolled growth in programs that primarily benefit the middle class" and indicating concern that lawmakers and voters are not willing to undertake the "shared sacrifice" necessary to regain budgetary control).

${ }^{173}$ Another example of a short-term political crisis overwhelming legislators' long-term interests may have occurred when they indexed brackets for inflation, depriving themselves of automatic tax rate increases.

${ }^{174}$ McChesney's work has appeared in a series of articles, most notably, Fred S. McChesney, Rent Extraction and Rent Creation in the Economic Theory of Regulation, $16 \mathrm{~J}$ Legal Stud 101 (1987). Recently, he compiled and extended his work in McChesney, Money 
The economic theory of legislation posits that the legislature works like a market, where interest groups compensate lawmakers for supplying them with a product: laws dispensing federal largesse. Theoretically, groups should be willing to pay legislators (through campaign contributions, in-kind benefits and other legal gifts, post-tenure employment, and the occasional illegal gratuity) up to the discounted present value of the benefit. ${ }^{175}$ The analogy to a free market is not exact, however, because a variety of laws limit such financial rewards and thus cap the price legislators can extract below the amount some interest groups would be willing to pay. Therefore, any major revenue bill enacts tax expenditures worth far more to groups than the groups spend to get them ${ }^{176}$ For example, the 1993 tax bill included targeted relief for the real estate industry estimated to reduce federal revenues by $\$ 9.1$ billion over the first five years of enactment; ${ }^{177}$ the provisions were worth much more than that to realtors, contractors, investors, and related industries. ${ }^{178}$ In 1992 through 1994, however, real estate interests contributed only $\$ 29.7$ million to the campaign coffers of members of Congress. ${ }^{179}$ In fairness, this figure is

for Nothing (cited in note 135). A simpler, but less persuasive, explanation than the one presented in the text is also possible. Lawmakers will be indifferent with respect to adopting offset requirements if the total benefits they receive under a system with PAYGO equal those in the alternative regime. Although any decline in durability caused by offset requirements means that benefits are worth less, perhaps more groups will be willing to enter the market for tax expenditures, maintaining lawmakers' aggregate compensation. The problem with this explanation is that it is difficult to imagine more buyers entering a market where the product has simultaneously become less valuable and more expensive. On the contrary, one would expect the number of buyers to decline. Perhaps they will pay more for the benefits than they did before PAYGO, which again may result in legislators receiving as much in interest group benefits as they do now; but limits on the amount of compensation that can be legally transferred, see text accompanying notes 175-79, suggest that the market cannot make that adjustment either.

${ }^{175}$ See Garrett, 81 Cornell L Rev at 686-87 (cited in note 7); Jonathan R. Macey, Promoting Public-Regarding Legislation Through Statutory Interpretation: An Interest Group Model, 86 Colum L Rev 223, 227-29 (1986).

${ }^{176}$ See, for example, Shaviro, $139 \mathrm{U} \mathrm{Pa} \mathrm{L}$ Rev at 73 (cited in note 67) ("One might observe that $\$ 6.7$ million [in campaign contributions to members of the tax writing committees] seems astoundingly cheap given the enormous stakes (in 1985, a typical recent year, the income tax took in roughly $\$ 400$ billion, or 60,000 times as much).").

${ }^{177}$ Joint Committee on Taxation, Summary of the Revenue Provisions of the Omnibus Budget Reconciliation Act of 1993 (H.R. 2264) 32-41 (GPO 1993).

${ }^{178}$ See National Association of Realtors, Deficit-Reduction Bill is Good for Real Estate and the Economy (Aug 3, 1993) (blaming changes in passive loss rules in the 1986 bill for part of the drop in the value of commercial properties by $\$ 500$ billion during the early 1990s); Clinton Speech to Realtors on Passive Loss Provisions, Other Parts of Tax Programs, Tax Notes Today Doc 93-9359 (Apr 29, 1993) (claiming that reduced interest rates would put hundreds of billions of dollars back into the economy); 139 Cong Rec S 1450 (Feb 4, 1993) (citing Mortgage Bankers Association study that claimed OBRA 1993 would cause property values to rise by 3 to 7 percent).

${ }^{179}$ These figures are derived from the Center for Responsive Politics Web Page, 
somewhat misleading. Most obviously, the amount of campaign contributions and other expenses understate the payments made to obtain the tax relief in many ways. First, efforts in earlier years laid the foundation for the 1993 changes. Second, individuals and groups who contributed may not be easily identifiable from available records as affected parties. Third, the figure does not include other lobbying costs. ${ }^{180}$ Finally, the figure does not include many gifts, trips, and future employment opportunities that were part of this deal. Furthermore, no rational group would pay as much as the present value of the $\$ 9$ billion tax subsidy, because at the time they incur the expenses there is no guarantee they will prevail. Legislative players operate in conditions of extreme uncertainty, and their willingness to compensate lawmakers is affected by that environment. Nonetheless, the payments by the real estate industry seem likely to be significantly lower than the groups would have been willing to pay for such substantial financial benefits.

If legislators face binding caps on the amount of payments they can receive from a group in any one period, one way around them is through installment payments. Moreover, if uncertainty about lawmakers' ability to deliver constrains interest groups' spending, it makes sense for the parties to agree to delay some of the payments until after performance. The challenge is to find a way to convince groups to continue to pay after they have received their tax benefit, that is, to reduce the chance of opportunistic behavior by federal beneficiaries before legislators have received all their compensation. Applying the concept of rent extraction here might lead to the conclusion that PAYGO operates as an enforcement clause because it provides a credible threat to holders of tax benefits that, absent continued compensation, Congress will withdraw their benefits and repeal the tax subsidy. Professor McChesney explains that:

[P]ayments to politicians often are made, not for particular political favors, but to avoid particular political disfavor, that is, as part of a system of political extortion, or 'rent extraction.' . . . Because the state, quite legally, can (and does) take money and other forms of wealth from its citizens, politicians

<http//www.crp.org/net/frsecret.html>, and the third and fourth edition of their publication, Larry Matkinson, ed, Open Secrets: The Encyclopedia of Congressional Money and Politics (CQ 3d ed 1994); Larry Matkinson, ed, Open Secrets: The Encyclopedia of Congressional Money and Politics (CQ 4th ed 1996).

${ }^{100}$ See John R. Wright, Interest Groups \& Congress: Lobbying, Contributions and Influence 11 (Allyn \& Bacon 1996) (estimating conservatively, using 1988 data, that the total operating cost for the entire lobbying industry is $\$ 12$ billion annually). 
can extort from private parties payments not to expropriate private wealth. ... In that sense, rent extraction-receiving payments not to take or destroy private wealth-is 'money for nothing,' in the words of the song. ${ }^{181}$

Rent extraction is hardly new in the tax legislative process. Indeed, McChesney has focused often on the tax writing committees as arenas where this kind of behavior is commonplace. ${ }^{182}$ Rent extraction is theoretically possible in any legislative realm because legislators always have the ability to repeal existing beneficial legislation or to enact burdensome laws. One of the conditions necessary for effective extraction, however, is that the victim must believe that the chances are great that Congress will overcome the hurdles to legislation and actually pass the harmful law. ${ }^{183}$ Even before offset requirements, the frequency with which Congress passed new tax legislation and decreased various tax subsidies produced enough uncertainty that current beneficiaries of tax expenditures might have been regularly worried that their provisions would be scaled back or eliminated. ${ }^{184}$ Professor Witte's study of tax expenditures demonstrates that before 1982, such provisions were decreased or restricted 64 of the 195 times they were modified (although expansion or increases were much more likely, occurring 117 times during this period). ${ }^{185}$ For the most part, however, before brackets were indexed and deficit concerns took center state, Congress was subject to very little pressure to restrict current tax subsidies.

Obviously, the scramble to find revenue prompted by offset requirements makes the threat of repeal all the more credible to

\footnotetext{
${ }^{182}$ McChesney, Money for Nothing at 2-3 (cited in note 135). See also McChesney, $16 \mathrm{~J}$ Legal Stud at 104-05 (cited in note 174).

${ }^{182}$ See McChesney, Money for Nothing at 62-66 (cited in note 135). See generally Doernberg and McChesney, 71 Minn L Rev 913 (cited in note 167); Richard L. Doernberg and Fred S. McChesney, Doing Good or Doing Well?: Congress and the Tax Reform Act of 1986, 62 NYU L Rev 891 (1987). See also Edmund Morris, The Rise of Theodore Roosevelt 171 (Coward, McCann \& Geoghegan 1979) (describing practice in New York state legislature of "strike bills" introduced to force companies to pay assembly members not to pass them).

${ }^{183}$ McChesney, Money for Nothing at 38 (cited in note 135).

${ }^{18}$ See William F. Shughart, Durable Tax Reform, 7 Cato J 273, 274 (1987) ('[R]epeated efforts at 'reform' create a situation in which tax shares are considered 'up for grabs' in each and every budgetary period. As a result, the reform process becomes an annual contest among interest groups to preserve existing tax preferences, or to shift tax liabilities to other groups.").

${ }^{165}$ Witte, Politics and Development of Income Tax at 319 table 15.4 (cited in note 66) (tabulating actions on general economic and special economic incentives). For special group incentives, which benefit organized groups but may not be designed to foster economic growth, the threat was even more credible because they were decreased or restricted ten times out of eighteen and expanded or increased only seven times.
} 
current beneficiaries. ${ }^{186}$ For example, Professor Witte compared the Tax Reform Act of 1986, which was considered pursuant to the informal norm of revenue neutrality, to previous tax bills and found that " $[\mathrm{b}] \mathrm{y}$ all measures, TRA dwarfs any of the three prior peacetime reform acts $\left(1969,1982\right.$, and 1984). ${ }^{n 187}$ The Act restricted seventy-two tax expenditures, completely repealing fourteen, "a figure approximately equal to the total number of tax expenditures that had been repealed from 1913 and 1985."188 Witte credits this change to the requirement of revenue neutrality within the tax code coupled with the decision not to raise income tax rates, conditions that continued to shape tax bills until the 1997 Taxpayer Relief Act, which used cuts in direct spending to fund tax breaks. ${ }^{189}$

Political scientists and other scholars have done very little careful analysis on the creation, modification, and repeal of tax expenditures since 1986. Witte's most comprehensive study extends only to legislation passed before 1982; others measure merely the rate of change, rather than its direction. ${ }^{190}$ More empirical work is needed to quantify precisely the effect of offset requirements on tax expenditures; however, we can conclude as a preliminary matter that PAYGO adds credibility to rent extraction strategies. Revenue bills affected by offset requirements have long sections of revenue-raising provisions, many of which scale back or eliminate tax expenditures. Since 1990, some legislation expanding entitlement programs also has been partially offset by higher tax revenue, further threatening the beneficiaries of tax subsidies. ${ }^{191}$ Although the pressure on current tax expenditures is less pronounced in the current budget environment in which entitlement reforms produce money for tax cuts, the Taxpayer Relief Act repealed or curtailed enough tax subsidies to raise nearly $\$ 110$ billion over ten years. ${ }^{192}$

Understanding this political reality, groups will be willing to pay lawmakers up to the amount of future expected benefits in

${ }^{105}$ See, for example, Morgenson, Forbes at 44 (cited in note 141) ("A Congressman need only say a few words about changing an aspect of tax law-and money pours in from lobbyists and PACs intent on averting a disaster.").

${ }^{107}$ John F. Witte, The Tax Reform Act of 1986: A New Era in Tax Politics?, 19 Am Pol Q 438,443 (1991). Witte explains his method of counting in Chapters 13 and 15 of his book, The Politics and Development of the Federal Income Tax (cited in note 66).

${ }^{10}$ Witte, $19 \mathrm{Am}$ Pol Q at 443.

100 Id at $445,447$.

${ }^{180}$ See note 167.

${ }^{191}$ See, for example, Emergency Unemployment Compensation Act of 1991, Pub L No 102-164, 105 Stat 1049, codified at 26 USC $\$ 6654$ (1994).

${ }^{192}$ Joint Committee on Taxation, Estimated Budget Effects (cited in note 98). 
order to convince legislators to spare their tax provision. Each session of Congress offers another opportunity to extract more political rent and requires additional resources for signaling. In other words, PAYGO increases the transaction costs facing interest groups, but allows legislators to receive some of the new payments. At the same time, lawmakers also will collect payments from groups seeking new benefits.

One problem with this analysis of the adoption of PAYGO is that it does not explain why legislators did not adopt the system before 1990. If rent extraction is a successful strategy for lawmakers, why did they wait so long to implement it or a similar installment-payment program (such as making tax subsidies temporary and requiring Congress to reenact them periodically)? This complaint is related to a frequently voiced criticism of the economic theory itself. Rent extraction, combined with the traditional economic model of legislation, allows scholars to explain every action we observe in Congress in terms of this market model; it thereby loses a great deal of its explanatory and predictive force. ${ }^{193}$ If legislation is enacted, then the beneficiaries must have outbid their rivals; if legislation is not enacted, the rivals clearly won. If a particular offset is used to pay for a new tax benefit, the holders of the repealed provision simply must not have paid enough to avoid the burden, perhaps erroneously believing that Congress was bluffing. If the offset is proposed but does not pass, holders of the targeted provision must have met the extortionate demand in order to continue enjoying the federal program. More importantly, the theory adopts the inaccurate view of legislators as one-dimensional seekers of financial rewards from special interest groups. While virtually all who wish to stay in Congress must seek campaign funds, many use their political offices not just to receive more financial compensation from special interests, but also to affect policy outcomes. Offset requirements, which make legislating more difficult, will frustrate these lawmakers' goals of exercising power and influence and of enacting particular federal programs through changes in the tax code. Using rent extraction to explain the adoption of PAYGO also ignores those members who sincerely support offset requirements as devices to reduce federal spending.

But I am using the notion of rent extraction for a rather limited purpose: to explain why offset requirements are not neces-

\footnotetext{
${ }^{193}$ See Shaviro, $139 \mathrm{U} \mathrm{Pa} \mathrm{L} \mathrm{Rev} \mathrm{at} 75$ (cited in note 67) (noting that rent extraction theory exacerbates the already great risk of reducing public choice theory to a tautology). See also id at 73-76 (criticizing Doernberg and McChesney's application of rent extraction theory to the 1986 Act).
} 
sarily incompatible with lawmakers' self-interest. ${ }^{194}$ This discussion is only part of a larger story of the current budget rules. Legislators may have a tendency to favor rent extraction strategies (or at least to give them serious consideration), but interest groups have every incentive to oppose them. Before PAYGO, interest groups were able to stave off most efforts to make tax subsidies temporary or to enhance rent extraction opportunities. As the size of the federal deficit became a substantial political issue and thus revenues became more constrained, the prior political equilibrium was upset, and institutional change became inevitable. When Congress enacted PAYGO in 1990, the norm of revenue neutrality had already been developed, although in part for different purposes, during deliberations of the 1986 Tax Reform Act. ${ }^{195}$ The prominence of this norm shaped the procedural response; congressional experience with this particular solution lowered the costs of building consensus in favor of the reform and imbued it with an air of legitimacy.

Members of Congress may have favored retaining the status quo without offset requirements because they preferred the freedom to dispense tax benefits. At least some of these members, however, did not oppose the reform because they knew, from experience, that such compensation would hardly disappear under the new system. ${ }^{196}$ Moreover, all members of Congress would not be affected in the same way by any particular budget change; such a divergence of interest may explain why some members supported PAYGO as the best of several bad alternatives. For example, due to the increase in downstreaming brought on by PAYGO, legislators with expertise in facilitating regulatory expenditures (as well as the President and Treasury officials) might have known that their skills would be in greater demand under a system that restricted the ability to pass legislative tax subsidies. The tax writing committees might have preferred that Congress not apply budget procedures to legislation within their jurisdic-

\footnotetext{
${ }^{19}$ Similarly, one need not explain all congressional behavior affecting the tax code in terms of rent extraction or public choice theory in order for the theory to be convincing or helpful. Some tax subsidies, such as need-based expenditures, may be best understood as consistent with the larger public interest. However, interest group politics and rent extraction may describe a great deal of the legislative activity at the margin. It also may characterize most of the activity with regard to changes to the Internal Revenue Code that Congress considers every one or two years when it enacts comprehensive tax bills.

${ }^{106}$ See text accompanying notes $27-28$.

${ }^{106}$ The total campaign receipts received by members of the tax writing committees in 1987-88 were over $\$ 55$ million; in 1989-90, they received nearly $\$ 43.5$ million; and in 1990 91, their campaign receipts were approximately $\$ 44$ million. The unusually high figure for the 1987-88 election cycle is partly explained by the fact that over half of the members of the Senate Finance Committee were up for reelection.
} 
tion, but once change became virtually inevitable, they could have determined that the overall effect of the 1990 reform strengthened them relative to members who do not serve on Ways and Means or Senate Finance. PAYGO allows these committees to construct important bills using entitlement programs within their jurisdictions and changes to the Internal Revenue Code, with no interference from appropriators and little from the budget committees. The new points of order strengthened the Rules Committee in the House, which has the ability to waive the objections in a special rule. ${ }^{197}$ The 1990 changes somewhat increased the importance of the budget committees in the process; the changes also empowered congressional leaders who play vital roles in coordinating legislation and negotiating during the budget summits that settle interbranch disagreements over major legislation.

Legislators were not the only interested parties who could have determined that offset requirements were not necessarily incompatible with their desire to raise money from interest groups. PAYGO and the other rules also benefit lobbyists, the agents of interest groups, because such procedures promise them continued compensation long after they succeed in convincing legislators to enact a tax expenditure. Lobbyists are often the reason that interest groups are well informed about the ramifications of legislative actions. In this instance, it might not have been in their interests to alert their principals to the threat posed by offset requirements or to lend their full energies to defeating their extension into the tax arena. The opacity of such procedures might have allowed lobbyists to deviate from their principals' interests without detection. In addition, some interest groups might have decided that PAYGO was the least detrimental method to control federal spending to meet the public demand for lower federal deficits. Groups that benefited from existing tax expenditures would favor, relative to other reforms, budget rules that protected the status quo. Although, compared to the situation before 1990, PAYGO reduces the durability of previously enacted provisions that become prey for funding predators, it might be less unsettling to established groups than a reform that would require regular sunsetting, and it certainly places more burdens on new entrants than it does on current beneficiaries.

This story of the adoption of PAYGO does not mean that offset requirements are meaningless or undesirable; indeed, they

\footnotetext{
${ }^{197}$ See Kiewiet and McCubbins, Logic of Delegation at 88-90 (cited in note 92) (noting that the points of order in the budget process significantly strengthened the House Rules Committee, which determines whether a special rule will waive the objections).
} 
appear to have restrained the amount of federal spending through the tax code, and they may have other beneficial effects that I shall now discuss. It merely means that their adoption is neither inexplicable nor necessarily heroic. ${ }^{198}$

\section{OFFSET REQUIREMENTS RESULT IN CONGRESSIONAL SCRUTINY OF EXISTING TAX EXPENDITURES}

The Department of Treasury released the first Tax Expenditure Budget several years before the 1974 Budget Act required the legislative and executive branches of government formally to disclose extensive information about tax expenditures. ${ }^{199}$ Proponents of vigorous tax expenditure review had advocated changes more far-reaching than mere disclosure, but they hoped that the additional information would allow policymakers to be "more concrete and precise about the objectives of our programs ... [to] [e]xamine longer term alternatives before reaching decisions ... [and to] [1]ink our planning efforts more directly to budget decisions. ${ }^{200}$ Ideally, legislators, armed with better data and fuller understandings, would review tax expenditures regularly and decide whether to retain them. The tax expenditure system would, in theory, no longer run on automatic pilot.

Whether this new access to information has brought about the anticipated periodic review is unclear. As promised, the budget process did result in a deluge of information. ${ }^{201}$ The wide availability of the information, however, has not resulted in any

${ }^{198}$ It may also be that the current situation is not stable. Just as the deficit targets imposed by GRH were first postponed and then eliminated, politicians may decide to repeal or weaken PAYGO if it disrupts rent-seeking and other political arrangements substantially. So far, evidence suggests that PAYGO is a stable outcome (it having been extended through 2002), but it does expire occasionally, requiring an affirmative congressional vote to remain in effect.

${ }^{109}$ See Bernard Wolfman, Tax Expenditures: From Idea to Ideology, 99 Harv L Rev 491, 494 (1985) (review of Surrey and McDaniel, Tax Expenditures (cited in note 25)); Theodore J. Eismeier, The Power Not to Tax: A Search for Effective Controls, $1 \mathrm{~J}$ Pol Analysis \& Mgmt 333, 336 (1982). See also Surrey and McDaniel, Tax Expenditures at 45 (cited in note 25) (detailing requirements of the Budget Act); Stanley S. Surrey, Pathways to Tax Reform: The Concept of Tax Expenditures (Harvard 1973) (discussing concepts by main proponent of the idea of tax expenditures and of the need for information in the policymaking process).

${ }^{200}$ Department of Treasury, Annual Report of the Secretary of Treasury for the Fiscal Year Ended June 30, 1968327 (GPO 1968). See also Eismeier, $1 \mathrm{~J}$ Pol Analysis \& Mgmt at 336 ("But its strongest proponents see the Tax Expenditure Budget as much more than a source of information.").

${ }^{201}$ The responsibility for disclosure is dispersed among numerous players: budget committees, tax writing committees, appropriations committees, and technical staffs in both the legislative and executive branches. 
regularized review process for tax expenditures. ${ }^{202}$ Instead, the primary mechanisms that ensure the information will actually affect tax policy are PAYGO and related offset requirements. ${ }^{203}$ Put simply, PAYGO creates a clientele for the review of tax expenditures. Moreover, offset requirements restructure the nature of congressional deliberation, often forcing members to compare new proposals with other proposals and existing provisions. Prior analysis of PAYGO has not recognized this effect; instead, some commentators have described offset requirements as affecting only new programs and ignoring, or even entrenching, the status quo. ${ }^{204}$ Certainly, the most salient effect of these rules is the burden they place on the enactment of new tax expenditures, but the informational consequences are felt more broadly. In the following Parts, I first will describe how conflict ensures that more information about tax expenditures is generated and that private parties who stand to gain from tax legislation bear some of the costs of disclosure. Then, I will assess whether this rather indirect enforcement mechanism can act as a relatively effective surrogate for more formalized review of tax subsidies. ${ }^{205}$

\section{A. Offset Requirements Provide Congress with More Information About Tax Expenditures}

PAYGO encourages private entities to supply and evaluate necessary information by rewarding them for participating in a certain kind of informed argument about tax expenditures. In a

\footnotetext{
${ }^{202}$ Stanley S. Surrey and Paul R. McDaniel, The Tax Expenditure Concept and the Legislative Process, in Henry J. Aaron and Michael J. Boskin, eds, The Economics of Taxation 123, 128, 143 (Brookings 1980).

${ }^{203}$ See Wildavsky and Caiden, New Politics at 134 (cited in note 8) (noting generally about offset requirements and budget rules that implementation of budget reform becomes easier because the participants will enforce it upon one another").

${ }^{204}$ See note 15 .

${ }^{200}$ This discussion may remind the court-centrists who have ventured into this study of the legislative process of the debate concerning the information-generating and information-structuring aspects of the adversarial system. See, for example, John C. Reitz, Why We Probably Cannot Adopt the German Advantage in Civil Procedure, 75 Iowa L Rev 987, 990-91 (1990) (describing the controversy over the comparative accuracy of the adversarial system and the Continental system); Samuel R. Gross, The American Advantage: The Value of Inefficient Litigation, 85 Mich L Rev 734, 742-44 (1987) (arguing that adversarial system produces more accurate information); Albert Alschuler, Mediation With A Mugger: The Shortage of Adjudicative Services and the Need for a Two-Tiered Trail System in Civil Cases, 99 Harv L Rev 1808, 1836-57 (1986) (arguing that, in part because of problems in factfinding inherent in an adversarial system with unevenly matched sides, discovery should be conducted primarily by a judge); John H. Langbein, The German Advantage in Civil Procedure, 52 U Chi L Rev 823, 841-48 (1985) (comparing the adversarial system to the Continental tradition of relying on the court to investigate and present the facts, and finding the latter preferable).
} 
way, this consequence is merely a different kind of rent extraction, because lawmakers obtain helpful information from private parties without compensating them. As advocates of new tax subsidies work to enact their programs, they research likely targets and share some of the information they develop with lawmakers and technical staffs. Although these groups most likely are interested only in discovering the strength of support for the current provision, their data may also shed light on whether a tax provision is efficient, whether it provides the intended incentive, or whether it has significant macroeconomic effects that current estimating techniques do not capture. The groups probably do not care whether a potential offset represents unwise public policy, but they nonetheless will often use policy arguments when they publicly justify their revenue-raising suggestions. ${ }^{206}$

Similar information is presented with respect to new tax expenditures. Advocates of proposed legislation always want to disclose favorable data to legislators, but, with PAYGO, the groups supporting the targeted offset counter the arguments in order to block the proposal's enactment. ${ }^{207}$ This safeguard works best when the latter groups have, and will spend, the resources necessary to counterattack. Even in the absence of an active prey, offset requirements may cause predators to fight among themselves for limited federal resources. In this battle, competing interest groups will produce information by comparing various new programs in an attempt to sell their particular proposal to lawmakers. Again, the ultimate decisions may turn largely on political considerations such as interest group clout and constituency concerns, but the public debate will encompass arguments on traditional tax policy grounds.

${ }^{206}$ See Jon Elster, The Market and the Forum: Three Varieties of Political Theory, in Jon Elster and Aanund Hylland, eds, Foundations of Social Choice Theory 103, 112-13 (Cambridge 1986) (suggesting that in public discourse, the requirement that at least lip service be paid to arguments about the public good may lead to sincere consideration of such reasons for action); Garrett, $45 \mathrm{U}$ Kan L Rev at 1178 (cited in note 32) (arguing that those who use policy arguments strategically in political debate may "spark sincere deliberation of those issues in appropriate cases"). See also Amy Gutmann and Dennis Thompson, Democracy and Disagreement 100-01 (Belknap 1996).

${ }^{207}$ On the policy benefit of such an effect, see Wright, Interest Groups \& Congress at 180 (cited in note 180) (noting that interest groups can mislead lawmakers and the public more easily in the absence of pluralistic conflict). See also id at 96 (describing the information strategies of interest groups as both proactive (to change a policy position) and counteractive (to prevent an opposing group from changing a policy position)); Epstein and O'Halloran, $11 \mathrm{~J}$ L Econ \& Org at 228-29 (cited in note 141) ("In all cases, a greater number of interest groups makes legislators better off, and in many cases they also make agencies better off, by reducing the uncertainty surrounding policy outcomes."). 
More information is not unambiguously good, however. Its benefits depend both on the cost of producing the information and the quality of the information disclosed. Without more study, it is difficult to assess the first factor, the cost of information. Because a large part of their daily activities concern gathering, processing, and disseminating information, organized interests are likely to be efficient producers of such data. ${ }^{208}$ They are information specialists, particularly with regard to their own interests and related programs. With offset requirements ubiquitous in budgeting, interest groups apply their sophisticated techniques to developing information about other groups' tax benefits that could serve as revenue-raisers. As one news source explained after GRH implemented offset rules for discretionary programs, "[i]nstead of concentrating on their own narrow interests, [corporate lobbyists] are gathering every shred of information they can find on the budget as a whole. ${ }^{209}$ Nonetheless, generating information through interest group conflict may be unnecessarily costly for society, even though this cost is not borne directly by the government; instead, it is externalized to those who benefit or hope to benefit from federal largesse. Without coordination, duplicative efforts are likely, not only by government entities producing the same information as private parties, but also by competing interest groups. Coordination can be achieved among the latter in coalitions of those with similar interests, but it is practically impossible between predator and prey or among predators.

If privately produced information is replacing government efforts, it could be saving government resources and reducing the overall cost. One way to test this hypothesis might be to compare the volume of government-provided information relating to tax expenditures before and after the adoption of offset requirements. I suspect, however, that such data would be relatively unhelpful. First, in the early years of the federal budget process, the idea of tax expenditures was relatively new to politicians, and the volume of official information might have been sub-optimal. Therefore, choosing an appropriate baseline and determining the cause for any variation will be difficult. Second, the government might

${ }^{200}$ See Robert H. Salisbury, The Paradox of Interest Groups in Washington-More Groups, Less Clout, in A. King, ed, The New American Political System 203, 225-26 (AEI 1990); Wright, Interest Groups and Congress at 75 (cited in note 180) (noting that interest groups achieve influence by strategically providing information to lawmakers).

${ }^{209}$ Wildavsky, New Politics at 257 (cited in note 1), quoting Ronald Grover, With Gramm-Rudman, Lobbying Will Never Be the Same, Business Week 33 (Feb 17, 1986). See also Wildavsky and Caiden, New Politics at 134 (cited in note 8) ("The entire budget, not just parts of special interest, has become relevant to all the participants."). 
be producing the same amount of information now but targeting it differently in order to concentrate on areas left undeveloped by interest group conflict. For example, government entities may have redeployed their resources to study revenue-losing structural changes that are favored by tax policy entrepreneurs but lack broader political momentum. ${ }^{210}$

Detecting any shift in the activity of government staff is particularly important because PAYGO applies to all revenue laws, setting up additional legislative hurdles whether the law is wise or unwise, whether it meets tax policy goals or undermines them. ${ }^{21}$ Take, for example, integration of corporate and individual taxes to reduce the effective rate on income produced through the corporate form. ${ }^{212}$ Given current estimating conventions, the Joint Tax Committee will score any integration proposal as losing significant revenue, which, under budget rules, must be offset. A provision such as integration that lacks strong interest group support and that does not resonate with the public is difficult enough to enact through the regular legislative process; ${ }^{213}$ offset requirements exacerbate the situation. While many organized groups favor integration, the benefits are so widely dispersed that interest group pressure in favor of this reform may be less intense than for benefits more fully internalized by the members. But if, as a response to budget conflict, private parties generate information regarding other tax proposals, the technical staff of the legislative and executive branches and other policy entrepreneurs may be able to spend more of their time on such a struc-

\footnotetext{
${ }^{210}$ Revenue-raising proposals that serve tax policy goals may be easier to pass after PAYGO than before because they will be supported not only by policy entrepreneurs but also by hungry predators searching for offsets. See John F. Coverdale, Text as Limit: A Plea for a Decent Respect for the Tax Code, 71 Tulane L Rev 1501, 1527-28 (1997) (noting that amendments closing tax loopholes are increasingly attractive because they can be used to meet offset requirements).

${ }^{211}$ See Garrett, $45 \mathrm{U}$ Kan L Rev at 1177 (cited in note 32) ("Indeed, one of the certain consequences of procedures that erect additional hurdles in the legislative process is that the inertia that characterizes the process will become further entrenched, making it more difficult to enact good laws, as well as bad ones.").

${ }^{212}$ See, for example, Department of the Treasury, Integration of the Individual and Corporate Tax Systems: Taxing Business Income Once vii-ix (GPO 1992). See also Alvin Warren, The Relation and Integration of Individual and Corporate Income Taxes, 94 Harv $L \operatorname{Rev} 719,798$ (1981) ("Integration of the individual and corporate income taxes, whether by shareholder credit or dividend deduction, would eliminate most of the defects of existing law.").

${ }^{213}$ Although strong business coalitions like the American Council on Capital Formation and the Business Roundtable have worked to enact capital gains relief, a proposal with many of the characteristics of integration discussed in the text, integration lacks the appeal with the public that the reduction in the capital gains rate appears to enjoy. Moreover, integration is only one of many tax policy reforms that lack strong constituencies and are difficult to enact even without the additional burden of the budget rules.
} 
tural issue neglected in the clash of interest groups. This increased attention may help overcome the legislative inertia that has been made stronger by the additional hurdle of PAYGO. ${ }^{214}$

Another factor that determines the value of information is its accuracy. Again, drawing firm conclusions here is difficult. The beneficiaries of tax expenditures and the proponents of new ones often have access to much better information about their businesses and their ability to use particular tax subsidies than do government experts. Indeed, in many cases, government estimators meet with affected parties to obtain information so that their projections will more accurately predict taxpayer behavior. ${ }^{215}$ On the other hand, interest groups have every incentive to skew information to favor their positions. The system, however, does provide a variety of rather porous checks on accuracy. The conflict engendered by budget rules acts may keep groups relatively honest because opponents will scrutinize their claims closely, and government specialists can spend time assessing the merit of private studies and other information. Policy entrepreneurs in think tanks and public interest organizations also may present critical perspectives and question the methodology employed by interested parties. Groups are well aware that if lawmakers or estimators catch them lying or misrepresenting facts, they may lose their credibility on the Hill and their access to key policymakers. That is a particularly potent enforcement mechanism with respect to lobbyists, who are repeat players and whose reputations for providing trustworthy information are among their most valuable assets. Although this informal sanction may work to discourage outright falsehoods, one suspects that most privately generated information, which is designed to further particular agendas, will be incomplete and somewhat biased.

Thus, the role of offset requirements and budget conflict in producing information is large but of questionable value. Certainly, groups augment government disclosure, but perhaps with some duplication of effort. Moreover, the information may not be as accurate as that which could be provided by more neutral sources. However, if it is dominated by offset requirements and

${ }^{211}$ Thus, one could study the subject matter of tax policy studies produced by government staff to measure the change over the relevant time period. Of course, it may be diffcult to find agreement on what constitutes a "good" structural change, but perhaps one could observe general trends.

${ }^{215}$ See Richard B. Stewart, The Reformation of American Administrative Law, 88 Harv L Rev 1669, 1714 (1975) (noting that administrative agencies tend "to rely . . . on facts and arguments by regulated firms," although in theory "agency staff can gather information on its own"). 
controlled by legislators willing to impose punishment on those caught lying, the system may provide internal safeguards. Offset requirements may play another, arguably more vital, role in the review process: they structure the presentation of privately produced and officially disclosed information to lawmakers so that it is easier to comprehend and to use as the basis for policy decisions.

\section{B. Offset Requirements Operate as a Surrogate for Institutionalized Tax Expenditure Review}

Regardless of who generates information, it only will be used effectively if there is a structure for disclosure followed by deliberation. Knowing this, advocates of tax expenditure analysis do not favor disclosure simply for disclosure's sake-they want the information actually to affect public policy. Supporters seem to envision a world where lawmakers absorb all imaginable information, consider all possible tax policy ramifications, and scrutinize all conceivable political considerations. ${ }^{216}$ For example, Professors Surrey and McDaniel argue that "orderly government requires both the development of criteria to determine the choice between tax and direct expenditures, and an analysis of the possible consequences of each choice. ${ }^{217}$ They do not indicate, however, how they expect Congress to undertake that analysis, nor do they acknowledge all the realities that face legislators with limited abilities to process information. ${ }^{218}$ In a review of their 1985 book on tax expenditures, Bernard Wolfman noted this problem in the tax expenditure agenda:

The legislative process is political. I believe that any effort to inject a mandatory, rigid mechanism into that process will fail. ... [Members of Congress] are likely to be more receptive to a tool they select because they find it right for the job at hand than they will be to a program they are told they must apply universally because rationality requires it. ${ }^{219}$

\footnotetext{
${ }^{215}$ See Eismeier, $1 \mathrm{~J}$ Pol Analysis \& Mgmt at 338 (cited in note 199) (also noting that "the problem Congress often faces is not getting more information but making use of information it already has, a process one former member of the Ways and Means Committee likened to 'getting a drink from a fire hydrant").

${ }^{217}$ See Surrey and McDaniel, Tax Expenditures at 27 (cited in note 25).

${ }^{218}$ See Louis Fisher, Presidential Spending Power 263-64 (Princeton 1975) (noting that the compilation, analysis, and dissemination of information must be done with a "fine sense of selectivity" and advising that "[d]istinctions need to be made between the routine and the significant").

${ }^{219}$ Wolfman, 99 Harv L Rev at 498 (cited in note 199).
} 
Professor Wolfman's accurate observation does not mean that we must give up on the effort to improve the tax legislative process, but it does suggest that we may have to be creative and that proposals must take politics into account.

Various methods to institutionalize tax expenditure analysis do exist. Successful structures would share at least two characteristics. First, the process should include some sort of enforcement, either formal or informal, to increase the chance that legislators actually will consider relevant information and arguments. For example, since 1981, the CBO has been required to produce information about the cost of complying with federal legislation for state and local governments. This information, however, played almost no role in congressional decisionmaking until 1996, when the Unfunded Mandates Reform Act established points of order to ensure its timely disclosure and to allow an opportunity for focused deliberation. ${ }^{220}$ No enforcement procedure can dictate the content of congressional deliberation or require that political decisions be made only on certain grounds. It can, however, allow an opportunity for discussion and make relevant issues more salient to legislators, interest groups, and the public. Second, the procedure must include heuristic or other devices to structure and limit information so that lawmakers do not find themselves paralyzed by an overwhelming amount of data. ${ }^{221}$

Several reforms along these lines have been suggested. For example, tax expenditures could be enacted with sunset provisions. This would give Congress a regular opportunity to consider the tax policy and political issues raised by the tax expenditure. ${ }^{222}$ Since the late 1970 s, a group of tax provisions has formed a package of "extenders" that Congress has enacted temporarily and extended periodically. ${ }^{223}$ These include the targeted jobs tax credit, $^{224}$ the orphan drug credit, ${ }^{225}$ the low-income housing credit, ${ }^{226}$ the exclusion for employer-provided educational assis-

${ }^{220}$ Pub L No 104-4, 109 Stat 48 (1995), codified at 2 USCA $§ \S 1501$ et seq (Supp 1997). See also Garrett, 45 U Kan L Rev at 1160 (cited in note 32).

${ }^{21}$ See Michael A. Fitts, Can Ignorance Be Bliss? Imperfect Information as a Positive Influence in Political Institutions, 88 Mich L Rev 917, 940-41 (1990) (explaining heuristics and how they can assist legislative analysis). 193.

${ }^{22}$ It would also give them an opportunity to extract rent. See text accompanying note

${ }^{223}$ See, for example, Joint Tax Committee, Description of a Proposal to Extend Certain Expiring Tax Provisions, Repeal the Luxury Excise Tax on Certain Items, and Adopt Revenue-Raising Provisions JCX-23-92 (June 16, 1992). See also Pat Jones, New Day May Dawn for Sunset Tax Provisions, Tax Notes 1587 (Mar 13, 1995).

${ }^{2 x}$ IRC $\S 51$ (1994).

${ }^{225}$ IRC § 45C (Supp 1997).

${ }^{205}$ IRC § 42 (1988). 
tance, ${ }^{227}$ and the deduction of health insurance costs for the selfemployed. ${ }^{228}$ Congressional scrutiny of these provisions has been relatively intense and certainly more sustained than the attention the legislature pays to most other tax expenditures. Congress also has refused to extend some of them, such as the exclusion for employer-provided group legal services, which expired in 1992. ${ }^{229}$ It has made others permanent, such as the low-income housing credit, which transcended extender status in the 1993 reconciliation act, ${ }^{230}$ and the health care deduction for the self-employed, which became permanent in $1996 .^{231}$ Meanwhile, others have changed form; the targeted jobs tax credit was transformed into the work opportunity credit in $1996,{ }^{232}$ although the transformation was primarily nominal. ${ }^{233}$ Thus, one way to institutionalize and enforce the opportunity for tax expenditure analysis is to sunset all such provisions periodically, perhaps in a staggered fashion. If Congress wanted to place more obstacles in the way of continuing provisions that are set to expire, budget rules could require that revenue lost from any reenacted provision be offset by spending reductions elsewhere in the budget.

Another reform would rely on a familiar device-the instructions to the committees in the annual concurrent budget resolution. ${ }^{234}$ The budget resolution could require that the tax writing committees reduce the amount of revenue lost through tax expenditures by a certain amount and enforce the requirement through a point of order procedure. More innovative reforms are also possible; for example, several senators have proposed a Corporate Subsidy Reform Commission that would identify and review "federal subsidies, including tax advantages, provided by the Federal Government to entities or industries in profit making en-

${ }^{227} \operatorname{IRC} \S 127$ (1994).

${ }^{228}$ IRC \& 162 (1994).

26 USC $\S 120(e)(1994)$.

${ }^{200}$ See OBRA 1993, Title XIII § 13142, 107 Stat at 438.

${ }^{201}$ Health Insurance Portability and Accountability Act of 1996 \& 311, Pub L No 104 191, 110 Stat 1936, 2053, codified at IRC \& 162 (Supp 1997).

${ }^{202}$ IRC $\$ 51$ (1994). See note 75.

${ }^{200}$ The work opportunity credit does, however, have fewer targeted groups, an increased minimum period in which the employee must work for an employer, and is slightly more generous. Another extender that has changed form is the credit for research and experimentation, IRC $\$ 41$ (1994); the Small Business Job Protection Act of 1996 $\S 1204$ added an alternative incremental credit to the traditional credit, although both remain temporary. Pub L No 104-188, 110 Stat 1755, 1773, codified at IRC \& 41 (Supp 1997).

${ }^{244}$ See Surrey and McDaniel, Tax Expenditure Concept at 144 (cited in note 202); Lance T. LeLoup, The First Decade: Evaluating Congressional Budget Reforms, in Kenneth A. Shepsle, ed, The Congressional Budget Process: Some Views from the Inside 129, 153 (Center for the Study of Am Bus 1980). 
terprises."235 The proposal would require the Commission to submit recommendations to the President and would allow Congress to consider through expedited procedures any of his suggestions. Congress could enact additional procedures to insulate the Commission's recommendations more completely from politics, following the example of the Base Closure and Realignment Commission, whose recommendations for closing military bases Congress had to accept or reject as a whole, without amending the Commission's list. ${ }^{236}$

These mechanisms are relatively straightforward attempts to scrutinize, and perhaps repeal, simplify, or otherwise modify, tax expenditures. They suffer, however, from a significant political problem that does not beset offset requirements-they require Congress to agree on what provisions should be considered as tax expenditures. ${ }^{237}$ Currently, Treasury and the Joint Tax Committee differ slightly in their understandings of the proper definition. ${ }^{238}$ More importantly, members of Congress find the concept to be highly contestable, with some members, including the chairman of the Senate Budget Committee, expressing fundamental disagreement with the basic notion that some tax provisions are the equivalent of federal spending and subsidy programs. ${ }^{239}$ Offset requirements, which indirectly spark a kind of

${ }^{255}$ The Corporate Subsidy Reform Commission Act of 1997, S 207, 105th Cong, 1st Sess, in 143 Cong Rec S 729 (Jan 28, 1997) (by Senator McCain and others). See Fitts, 88 Mich L Rev at 963-64 (cited in note 221) (discussing tool of government commissions as a strategy to manage information).

${ }^{236}$ National Defense Authorization Act for Fiscal Year 1991, Title XXIX: Defense Base Closures and Realignments $\S 2908(d)(1)-(2)$, Pub L No 101-510, 104 Stat 1485, 1817 (1990).

${ }^{207}$ I am assuming that Congress would want to apply enforcement provisions only to a limited set of tax provisions, rather than implementing a review procedure for all tax provisions, even those necessary to define the tax base accurately.

${ }^{238}$ See Budget of the United States Government Fiscal Year 1998, H Doc 105-003 at 8485 (cited in note 58) (describing difference in the normal tax baseline used by Joint Tax and the reference tax baseline used by the administration, the measures used to determine deviations). See Wolfman, 99 Harv L Rev at 492 (cited in note 199) (summarizing the difference between tax expenditures and normative provisions).

${ }^{229}$ See Victor Thuronyi, Tax Expenditures: A Reassessment, 1988 Duke L J 1155, 1171 (noting that many members of Congress see repealing a tax expenditure as a tax increase, not a spending reduction). See, for example, 142 Cong Rec S 5252 (May 17, 1996) (remarks of Senator Domenici) ("What are tax expenditures and corporate loopholes? Frankly, there are two ways to look at it. One way to think about it is they were taxes that the Government owned, and we said we are not going to collect them. That is a Democrat version of a tax expenditure. The other version is they belong to the taxpayer and not the Government.”); 132 Cong Rec E 899 (Mar 20, 1986) (remarks of Harry K. Wells, put into the record by Representative Helen Delich Bentley) ("[S]ome personal tax deductions including interest paid on home mortgages are being referred to as tax expenditures to the taxpayer, an interesting turn of phrase! Clearly indicating the idea, it's the government's money that they are expending on you-a pretty scarey [sic] prospect for a country that believes 
tax expenditure analysis, may be superior to other proposals because no definition of tax expenditure is necessary as a threshold matter. Rather, current budget rules rely on the groups themselves to target particular provisions to raise revenue. My previous analysis suggests that many of these will inevitably be tax expenditures as policy analysts have come to use that term. Further empirical work on the nature of tax provisions that have been used to raise revenue under PAYGO is needed to confirm this conclusion; however, any casual analysis of the revenue provisions of tax bills during this decade indicates that the drafters of tax bills raise substantial revenue by modifying economic incentives and other special benefits in the tax code, as well as by enacting higher excise taxes and (usually disguised) tax rate increases.

If offset requirements institutionalize a kind of tax expenditure analysis that avoids controversial political difficulties because they do not require Congress to define precisely the notion of tax expenditure, why has this positive consequence of the budget rules been overlooked? The real problem may be that the review prompted by PAYGO is not the same as that envisioned by theorists who favor tax expenditure analysis. For example, one goal of tax expenditure review is to simplify the tax code, in most cases through repealing tax expenditures (and perhaps replacing them with direct subsidies) or by streamlining the provisions that survive scrutiny. ${ }^{240}$ The kind of review prompted by offset requirements seldom leads to greater simplicity in the tax code. Rather, it leads to an opposite result; compromise is forged through legislative deals that further complicate the revenue laws. ${ }^{241}$ In the few cases of outright repeal, transition provisions often complicate the tax system. Those who propose revenueraising provisions will agree to carve out exemptions for stronger interest groups, or they will redraft offset proposals so that beneficiaries still receive some, albeit less generous, subsidy though the tax code. This kind of compromise results in increased complexity; for example, the opposition to the depreciation recapture provision in the 1997 Taxpayer Relief Act resulted in an entirely different tax rate for this kind of gain-neither the new capital

in free enterprise and democracy.").

${ }^{20}$ See, for example, Surrey and McDaniel, Tax Expenditures at 26 (cited in note 25); Shapiro, Complexity in the Tax Legislative Process at I-J-8 (cited in note 14).

${ }^{241}$ See Elizabeth Garrett, The Legislative Process and the Dynamics of Tax Complexity, Testimony before the National Commission on Restructuring the Internal Revenue Service (Nov 8, 1996) (on file with U Chi L Rev). 
gains rate nor the rate for ordinary income. ${ }^{242}$ Review that results in greater complexity is particularly troubling because the obfuscation inherent in complicated tax laws reduces legislative accountability. ${ }^{243}$ This consequence undermines one of the primary objectives of both tax expenditure analysis and the budget process: to increase the transparency of congressional decisionmaking.

More generally, there is no reason to believe that, in the course of the offset process, tax expenditures are reviewed along the dimensions that tax policy analysts deem important. Although participants in the tax legislative process have long been attacked as insufficiently attentive to "significant tax policy analysis, ${ }^{, 24}$ these cries are louder now that budget considerations hold a more prominent position during the bills' formulation. Advocates of new spending probably do not choose to target existing provisions because the proposed offsets violate good tax policy; instead, they seek out provisions that will raise sufficient revenues while sparking minimal opposition. In other words, the considerations used in targeting are not necessarily close proxies for the considerations that drive ideal tax policy analysis. Even if the interest groups' arguments are couched in terms of efficiency, equity, and other noble principles, this rhetoric is usually cloaking the power struggle that actually will determine the outcome.

These criticisms may be on the mark, but they also can be aimed at the more formalized review structures that tax policy analysts have traditionally supported. Political considerations will force compromise regardless of the forum, and compromise causes complexity. When the interests of strong, organized groups clash with the objective of simplification, politicians usually side with the former. ${ }^{245}$ Because of the truncated budget window, however, PAYGO may cause more complexity in the tax laws than other forms of institutionalized review. As I discussed previously, predators try to draft their tax expenditures so that most of the revenue loss occurs in the out-years and so that any

${ }^{212}$ See Taxpayer Relief Act of $1997 \S 311,111$ Stat at 836.

${ }^{213}$ See Shuman, Politics and the Budget at 337 (cited in note 9). See also Joseph $M$. Bessette, The Mild Voice of Reason: Deliberative Democracy and American National Government 214-15 (Chicago 1994) (listing complexity as an impediment to public deliberation).

${ }^{2 *}$ See Shapiro, Complexity in the Tax Legislative Process at I-J-14 (cited in note 14).

${ }^{24}$ See Report of the National Commission on Restructuring the Internal Revenue Service, $A$ Vision for a New IRS 36-37 (June 25, 1997) (recommending adoption of procedures, including a Tax Complexity scorecard, to increase the prominence of issues of complexity in the legislative process); Gene Steuerle, Who Makes the Case for Tax Simplification?, Tax Notes 279 (July 14, 1997). 
behavior that would result in revenue gains occurs in the early years. ${ }^{246}$ The result is greater complexity than the inevitable political compromises would bring; one need only look at the provisions establishing the back-loaded Roth IRA to understand how the budget window, together with a cash-flow method of valuation, undermines the objective of simplification. Nonetheless, no form of tax expenditure review is likely to force lawmakers to pass simple laws at the cost of interest group support.

The experience with extenders--the tax provisions that expire, forcing congressional reconsideration every few years-suggests that many of the problems that arise with PAYGO will also plague other efforts to institutionalize and enforce tax expenditure review. ${ }^{247}$ Take the example of the targeted jobs tax credit. The vast majority of studies on the targeted jobs tax credit suggested it had only a minimal effect on employer hiring decisions and did not lead to permanent jobs. ${ }^{248}$ Nevertheless, Congress consistently extended the credit, made it permanent at one point, and finally "reformed" it by making only slight modifications (including reinstating its temporary status) and changing its name. It was not simplified, nor was it revised significantly to incorporate the tax policy concerns voiced during oversight hearings. On the other hand, just as the traditional approaches to tax expenditure analysis may cause lawmakers to assess the efficiency, complexity, and fairness of the status quo, so may the deliberation sparked by offset requirements. Procedural frameworks cannot dictate the content of congressional deliberation; they can only help to give members the opportunity to deliberate and to increase the chance that voters will be able to hold their represen-

\footnotetext{
${ }^{246}$ See text accompanying notes 96-102.

${ }^{207}$ Perhaps tax policy considerations are more likely to play a role if politically insulated commissions conduct the review. But such commissions are not entirely free from political influences, and their recommendations ultimately reach the legislative and regulatory arenas, where the typical political concerns largely determine their fate. In addition, it is not clear that decisions about the structure of the tax law are properly made by actors who are relatively unaccountable to the electorate; rather, they seem the kind of decision most properly vested in democratic institutions. See Eismeier, $1 \mathrm{~J}$ Pol Analysis \& Mgmt at 339 (cited in note 199) (citing as a misperception the view "that normative judgments about taxation and other policies should be made though a technical analytical process rather than through political interaction"). See also Wildavsky, Politics of the Budgetary Process at 191 (cited in note 9) (arguing that budgeting in general should take account of political considerations).

${ }^{213}$ See, for example, John H. Bishop and Mark Montgomery, Does the Targeted Jobs Tax Credit Create Jobs at Subsidized Firms?, 23 Industrial Relations 289 (1993); Hearings on the Targeted Jobs Tax Credit before the Employment, Housing, and Aviation Subcommittee of the House Committee on Government Operations, 103d Cong, 2d Sess (Sept 20, 1994) (testimony of Charles C. Masten, Inspector General of the Department of Labor).
} 
tatives accountable. In some cases they can increase the salience of certain issues for both policymakers and voters.

The role that PAYGO and offset requirements can play in tax expenditure analysis has been overlooked and underappreciated. My goal in this Part has not been to convince readers that such rules are the only or necessarily the best way to institutionalize review. Rather, I hope to show that they may avoid the difficult political problem of reaching a widely accepted definition of tax expenditures, while achieving review of existing and proposed tax subsidies that differs little from the deliberation that the oversight procedures long advocated by tax policy analysts would produce. Focusing attention on PAYGO, an existing real-world provision, is also a more practical approach than continued emphasis on idealized procedures that have yet to interest lawmakers.

As policymakers come to view PAYGO as the key element in structuring sustained consideration of tax expenditures, they may wish to consider amendments to the budget rules to toughen that review. If the availability of money in the direct spending arena is reducing pressure on tax provisions, then PAYGO could be narrowed so that revenue neutrality in tax legislation could come only from other changes in the code, not in decreased entitlement spending. Alternatively, Congress could amend the budget rules to require proponents of new tax subsidies to raise $\$ 2$ in revenues for every $\$ 1$ of new tax subsidy they receive, thereby prompting greater pressure for oversight of the current system. ${ }^{249}$ Such a change, accompanied by lockbox provisions to ensure that the savings are not used in subsequent bills for new programs, would also transform offset requirements from deficit control weapons to deficit reduction tools by increasing the revenue the government takes in with every new tax bill. Thus, consideration of this reform would include determining whether the public supported larger budgeting outcomes, as well as assessing the reform's effects on PAYGO's important informationstructuring role. If lawmakers come to view PAYGO as a way to enforce tax expenditure review, they may be more likely to retain the procedure even in years when the federal budget is balanced

\footnotetext{
${ }^{249}$ I am indebted to George Yin for discussions on this issue. See Midcourse Review of the Budget Enforcement Act, Hearing before the House Budget Committee's Task Force on Budget Process, Reconciliation and Enforcement, 102d Cong, 1st Sess 61 (Oct 10, 1991) (statement of Allen Schick) (urging that PAYGO "be revised to commit [at least] a portion of legislated revenue increases to reducing the deficit"). Congress has used procedural devices such as deficit lockboxes to ensure that money raised through changes to the tax laws or through program elimination is used to reduce the federal deficit rather than remaining available to offset new spending.
} 
or in surplus..$^{250}$ In the end, a better strategy for proponents of rigorous and meaningful tax expenditure analysis is likely to be modifying PAYGO, a procedure that is an established part of the tax legislative process, rather than continuing to advocate the adoption of other mechanisms that might spark congressional deliberation of these issues.

\section{CONCLUSION}

Competition among interest groups in budgeting is inevitable, so congressional procedures should be constructed to harness this competition in order to use it to its fullest advantage. After more than a decade of experience with offset requirements in the tax legislative process, we can now assess their value and consider changes. The necessity of this sort of analysis may be even more pressing as Congress continues to consider constitutionalizing a balanced federal budget. ${ }^{251}$ Reaching the best decision about this reform, or other budget proposals, requires a full understanding of all the costs and benefits, as well as a sophisticated awareness of the ways that offset requirements actually reduce the level of new federal spending, in the tax code and elsewhere. As part of this analysis, policymakers should give due consideration to the previously unidentified benefits of offset requirements: their role in both producing information about federal tax programs and structuring informed deliberation about allocative choices.

${ }^{250}$ See Letter to Pete V. Domenici, Chairman of the Senate Budget Committee, from June E. O'Neill, Director of the CBO (Oct 29, 1997) (on file with U Chi L Rev) (providing CBO's analysis of the statutory language establishing PAYGO and stating that the provision would apply to revenue and direct spending legislation whether or not the federal government was running a budget deficit).

${ }^{251}$ See Theodore P. Seto, Drafting a Federal Balanced Budget Amendment that Does What it is Supposed to Do (And No More), 106 Yale L J 1449 (1997); Shaviro, Do Deficits Matter? at 256-68 (cited in note 94). 


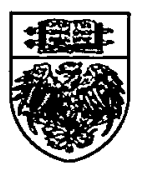

